Geobios

June 2017, Volume 50, Issue 3, Pages 237-257

http://dx.doi.org/10.1016/i.geobios.2017.04.004

http://archimer.ifremer.fr/doc/00385/49658/

(c) 2017 Elsevier Masson SAS. All rights reserved.

\title{
The Apennine foredeep (Italy) during the latest Messinian: Lago Mare reflects competing brackish and marine conditions based on calcareous nannofossils and dinoflagellate cysts
}

\author{
Pellen Romain ${ }^{1,{ }^{*}}$, Popescu Speranta-Maria ${ }^{2}$, Suc Jean-Pierre ${ }^{3,{ }^{*} \text {, }}$ \\ Melinte-Dobrinescu Mihaela Carmen ${ }^{4}$, Rubino Jean-Loup ${ }^{5}$, Rabineau Marina ${ }^{1}$, Marabini Stefano ${ }^{6}$, \\ Loget Nicolas ${ }^{3}$, Casero Piero ${ }^{7}$, Cavazza William ${ }^{8}$, Head Martin J. ${ }^{9}$, Aslanian Daniel ${ }^{10}$
}

${ }^{1}$ Université de Bretagne Occidentale, IUEM, Domaines océaniques, UMR 6538 CNRS, 1 place Nicolas Copernic, 29280 Plouzané, France

${ }^{2}$ GeoBioStratData.Consulting, 385 route du Mas Rillier, 69140 Rillieux la Pape, France

${ }^{3}$ Sorbonne Universités, UPMC University Paris 06, CNRS, Institut des Sciences de la Terre de Paris (iSTeP), UMR 7193, 4 place Jussieu 75005 Paris, France

${ }^{4}$ National Institute of Marine Geology and Geoecology, 23-25 Dimitrie Onciul Street, P.O. Box 34-51, 70318 Bucharest, Romania

${ }^{5}$ TOTAL, TG/ISS, CSTTF, Avenue Laribeau, 64018 Pau Cedex, France

${ }^{6}$ Museo Geologico Giovanni Capellini, Dip BiGeA, Università di Bologna, Via Zamboni 63, 40126

Bologna, Italy

${ }^{7}$ Via Enrico di S. Martino Valperga, 57, Roma, Italy

${ }^{8}$ Dipartimento di Scienze Biologiche, Geologiche e Ambientali, Università di Bologna, Piazza di Porta San Donato 1, 40126 Bologna, Italy

${ }^{9}$ Department of Earth Sciences, Brock University, 1812 Sir Isaac Brock Way, St. Catharines, Ontario L2S 3A1, Canada

${ }^{10}$ IFREMER, UR Geosciences Marines, BP 70, 29280 Plouzané, France

* Corresponding authors : Romain Pellen, email address : romin.pellen@gmail.com ; Jean-Pierre Suc, email address : jeanpierre.suc@gmail.com

\begin{abstract}
:
Sediments deposited after the peak of the Messinian Salinity Crisis (MSC) in the Apennine foredeep of Italy embody a topic debated on both chronostratigraphic and palaeoenvironmental grounds. We performed micropalaeontological (calcareous nannofossil and dinoflagellate cyst) analyses on four stratigraphic sections (Monticino, Civitella del Tronto, Fonte dei Pulcini, Fonte la Casa) and reused those previously published from Maccarone. All sections belong to the $\mathrm{p}$-ev2 $\mathrm{Fm}$. that includes the Colombacci deposits, usually considered emblematic of the Lago Mare in the area. Marine microfossils recorded in previous studies have often been neglected or considered reworked and hence discarded. We propose the occurrence of at least four marine inflows between 5.36 and $5.33 \mathrm{Ma}$, the first of which is reflected in the Apennine foredeep by marine dinoflagellates that are then replaced by Paratethyan (brackish) ones. Paratethyan species occupied favourable environments during intervals separating
\end{abstract}


marine inflows while the marine species survived elsewhere. From this perspective, the Apennine foredeep was an isolated perched basin during most of the peak of the MSC (5.60-5.36 Ma), and was progressively and repeatedly invaded by marine waters overflowing a palaeo-sill before the beginning of the Zanclean (5.33 Ma) which itself reflects a continuing eustatic rise. The Gargano Peninsula and, offshore, the present-day Pelagosa sill may be regarded as the remnants of this Messinian sill. This interpretation provides new possibilities for ecostratigraphically correlating the sections with Lago Mare biofacies, the deposition of which unquestionably started prior to the deposition of Colombacci sediments and continued into the earliest Zanclean. The results of this study show that the Lago Mare facies cannot be restricted to a single brackish palaeoenvironment but included competing marine and brackish waters controlled by geographic and chronological factors. Deposits overlying the unconformity separating the regional $p$-ev1 and p-ev2 formations are considered to represent the first marine incursion into the Apennine foredeep. These results allow us to refine the palaeogeographic reconstruction of the Apennine foredeep during the peak of the MSC. Although this basin was deep, its history during the peak of the MSC did not parallel that of the central Mediterranean basins.

Keywords: Dinoflagellate cysts, Calcareous nannoplankton, Lago Mare, Colombacci deposits, Apennine foredeep, Palaeo-sill 


\section{Introduction}

The Apennine foredeep (Fig. 1) is a sedimentary basin filled mostly by thick Neogene sediments, including Messinian deposits of the turbiditic Laga succession and a wide array of evaporites, overlain by the Zanclean Argille Azzurre (Fig. 2; Crescenti, 1975; Milli et al., 2007). This foredeep has been considered a perched basin during the peak of the Messinian Salinity Crisis (MSC) (Corselli and Grecchi, 1984; Clauzon et al., 1997, 2005), isolated from the almost completely desiccated Mediterranean Basin by a palaeo-sill, most probably in the area of the present-day Pelagosa sill (Figs. 1, 2; Bache et al., 2012). The Messinian postevaporitic deposits are subdivided into two formations: $\mathrm{p}-\mathrm{ev}_{1}$ and p-ev (Fig. 2; Roveri et al., 2001). The p-ev Fm. is devoid of fossils and mainly comprises thin-bedded siliciclastic turbidites considered to have been deposited in deep, fresh water conditions (Roveri et al., 2001). The p-ev 2 Fm. (5.36-5.33 Ma in Bache et al., 2012; 5.42-5.33 Ma in Roveri et al., 2014) includes in its upper part the "Colombacci Formation" (Selli, 1952, 1954; Roveri et al., 1998), which is characterized by prevalent clays alternating with thin micritic limestones and is known for its Paratethyan fossils (Lago Mare biofacies; Selli, 1973; Colalongo et al., 1976; Corradini and Biffi, 1988). A brackish faunal association based on molluscs (dreissenids, limnocardiids) and ostracods (mostly Cyprideis, loxoconchids) is generally considered characteristic of this unit (Gillet, 1968; Colalongo et al., 1976; Bellagamba, 1978; Esu and Taviani, 1989; Faranda et al., 2007; Gliozzi et al., 2007; Esu and Girotti, 2008). However, marine organisms have long been reported from this unit: foraminifers ${ }^{(f)}$, calcareous nannofossils $^{(\mathrm{n})}$, dinoflagellate cysts ${ }^{(\mathrm{d})}$, and fishes ${ }^{(\mathrm{fi})}$ (Cremonini et al., 1973 ${ }^{\mathrm{f}}$; Carloni et al., 1974 f Casati et al., 1976 ${ }^{\mathrm{f}}$; Colalongo et al., $1976^{\mathrm{f}}$; Crescenti et al., 2002 $2^{\mathrm{f}, \mathrm{n}}$; Bassetti et al., 
$2003^{\text {f }}$; Bertini, 2006 ${ }^{\text {d }}$ Carnevale et al., 2006a ${ }^{\text {fi }}$; Popescu et al., 2007 ${ }^{\text {fn,d; }}$; Trenkwalder et al., $2008^{\text {f,n }}$; Cosentino et al., $2012^{\text {n,d }}$; Luchetti in Brozzetti et al., in press $\left.{ }^{\mathrm{n}}\right)$. Such fossils have largely been dismissed as reworked (Casati et al., 1976; Bassetti et al., 2003; Trenkwalder et al., 2008) or simply neglected because of the difficulty in explaining the co-occurrence of marine and brackish microplankton (Bertini, 2006; Cosentino et al., 2012). Microfossils can often be established as reworked if they are broken and/or abraded. If the microfossils are well preserved, it is still possible to invoke reworking but only for species that existed before the MSC. Ceratolithus acutus (Gartner and Bukry, 1974) [= C. armatus (Müller, 1974)] is a short-lived calcareous nannofossil which first appeared at 5.35 Ma (Raffi et al., 2006; Anthonissen and Ogg, 2012), i.e., just before the initial deposition of the Colombacci sediments. The lowest occurrence of this species is the first biostratigraphic event after the Mediterranean marine reflooding which is estimated at 5.46 Ma (Bache et al., 2012), prior to the Zanclean GSSP (Global boundary Stratotype Section and Point) at 5.33 Ma (Hilgen et al., 2012). Accordingly, the presence of C. acutus in the Colombacci deposits, as shown at Maccarone (Popescu et al., 2007) and Civitella del Tronto (Luchetti in Brozzetti et al., in press), is a robust indicator of marine conditions beneath the lowermost Zanclean Argille Azzurre ("Blue Clays").

This work aims to verify and better constrain the suggested marine conditions of the Colombacci sediments by integrating dinoflagellate cyst and calcareous nannoplankton analyses from five sections along the Apennine foredeep. From north to south, the studied sections are (Fig. 2):

- Monticino in a marginal position;

- Maccarone in the wedge-top basin, which provides useful data (Popescu et al., 2007) for comparison;

- Civitella del Tronto in the deepest part of the foredeep;

- Fonte dei Pulcini and Fonte la Casa in the outer foredeep.

We pay special attention to the detection of reworked specimens. Indeed, reworking is a common phenomenon in the Mediterranean Basin, particularly at the end of the MSC when increased fluvial flows and then marine inflows resulted in significant erosion and redeposition. The debate surrounding this problem is vigorous (Corbi et al., 2016) and the Lago Mare biofacies from the Apennine foredeep is not spared from contention, as illustrated by opposing interpretations of the Maccarone section (Popescu et al., 2007, 2008 vs. Roveri et al., 2008). 


\section{Methods}

A few grams of sediment were used to prepare smear slides for microscopic examination of the calcareous nannofossils under bright light and polarized light at $\times 1600$ magnification. Their taxonomic identification followed Perch-Nielsen (1985) and Young (1998). Each sample was carefully analysed, with more than fifty fields of view being examined in order to find rare specimens (Fig. 3). In general, reworked calcareous nannofossil taxa may appear moderately well preserved, as with the in-situ specimens. Understandably, this can be problematic for nannofossil biostratigraphy for any succession of any age. In the studied sections, reworked taxa from older deposits, i.e., Paleogene and Cretaceous, have been identified but their abundance never exceeds $15-20 \%$. The nannofossil assemblages in general are moderately preserved and show no erratic fluctuations in composition, so we assume that their original composition is maintained. Concerning the presence of Ceratolithus acutus below the base of the Zanclean, we contend that specimens are in situ; their low abundance, i.e., always below $1 \%$, is similar to that recorded from the basal Zanclean by various nannofossil workers (Di Stefano and Sturiale, 2010). Similarly, the nannofossils Triquetrorhabdulus rugosus and Amaurolithus spp., markers of the Messinian-early Zanclean interval, are always recorded in very low numbers in the Mediterranean (Castradori, 1998). However, some species encountered in our study have been discarded as incompatible with the age of the p-ev ${ }_{2}$ Fm., such as Discoaster quinqueramus (see Sections 4.1., 4.3., and 4.4.). Some of the considered calcareous nannofossils are shown in Fig. S1 (Appendix A).

For the analysis of dinoflagellate cysts, samples weighing 10-15 grams were processed as follows: acid treatments using $\mathrm{HCl}, \mathrm{HF}$, and $\mathrm{HCl}$ again, followed by concentration in $\mathrm{ZnCl}_{2}$ at density 2.0 , and sieving at $10 \mu \mathrm{m}$; a $50 \mu 1$ volume of residue was mounted in glycerine and examined under a light microscope (magnification: $\times 1000$ ). Microscope slides were also examined using fluorescence microscopy to help with the identification of reworked specimens (Van Gijzel, 1967; Doláková and Burešová, 2007). Dinoflagellate cyst taxa were grouped according to their ecological tolerance, nutritional strategy, and geographical provenance based on Warny and Wrenn (2002), Londeix et al. (2007), and Popescu et al. (2009) (Appendix A: Table S1). Because their motile stage lives in surface waters, dinoflagellates are sensitive to changes in salinity and thus to water incursions, such as freshwater inflows, and influxes of marine and/or brackish (notably Paratethyan) water masses that potentially affected the Apennine foredeep during the late Messinian. Accordingly, dinoflagellate cysts were grouped into two associations: "marine" (including euryaline and stenohaline), reflecting the influence of Mediteranean waters, and 
"Paratethyan", comprising endemic species associated with more brackish conditions (Appendix A: Table S1). Counts provided in Table S1 indicate abundant reworked dinoflagellate cysts in some samples: under fluorescence microscopy, they exhibit a yellowish to orange colour with low intensity that makes them recognizable from the insitu specimens, the latter displaying a greenish to yellowish colour with high intensity (brightness). Most reworked specimens belong to species that disappeared before the Late Miocene (Appendix A: Fig. S2).

\section{Studied sections}

\subsection{Monticino}

Forty-five kilometres southeast of Bologna, near Brighella (Faenza), the Monticino quarry is now a Geopark (4413’32” N; 1145’53” E; Figs. 2(a), 4(a); Vai and Ricci Lucchi, 1977). It shows Colombacci deposits sandwiched between the Messinian Primary Lower Gypsums and the Zanclean Argille Azzurre (Figs. 2(b), 4(a, b); Marabini and Vai, 1989). The thin (2-3 m) Colombacci deposits unconformably overlie the gypsums (Figs. 2(b), 4(b)). Usually known as the intra-Messinian unconformity and being interpreted as exclusively tectonic in origin (Marabini and Vai, 1985; Roveri et al., 2005), this unconformity was called the Messinian Erosional Surface (MES) by Clauzon et al. (1996) who observed it in a fluvial erosional context relative to the Messinian sea-level drop. Only six or seven lower gypsum beds are visible at Monticino instead of the 16 beds forming what is known in the area as the Vena del Gesso, extending some 20 km northwestwards (Vai and Ricci Lucchi, 1977; Roveri et al., 2008a). The overlying Colombacci sediments mostly comprise dark-grey to green, brown and black brackish clays with Paratethyan molluscs (Dreissena simplex, Melanopsis marzolina, Adacna simplex, some limnocardids, etc.; Taviani, 1988) and ostracods (Cyprideis gr. pannonica; Colalongo, 1988). This succession is conformably overlain by the Argille Azzurre. The Colombacci sediments also fill karstic fissures that were cut during the erosional phase. These infilling sediments have yielded a late Messinian vertebrate fauna mainly composed of mammals (De Giuli et al., 1988; Rook et al., 2015).

The Colombacci deposits contain some marine molluscs such as Chlamys, and also some planktonic marine microfossils including foraminifers (Colalongo, 1988) and dinoflagellate cysts (Bertini, 2006) that have been considered reworked or contaminants from the overlying Argille Azzurre, or simply disregarded. Allowing for the prospect of marine fossils occurring within the Colombacci deposits at Monticino, we deemed it necessary to clarify this matter. Eight samples were taken and analysed for calcareous nannofossils and dinoflagellate cysts: 
five from the stratified Colombacci deposits on the northern edge of the quarry (Fig. 4(b, c)), and three from a Colombacci-filled karstic fissure ( $\left.\mathrm{n}^{\circ} 8 \mathrm{bis}\right)$ on the southern edge of the quarry (Fig. 4(d, e)).

\subsection{Maccarone}

Near the town of Apiro in the Marche region, the Maccarone section (4324'20" N; 0³9’00” E; Fig. 2) is characterized by ca. $100 \mathrm{~m}$ of p-ev ${ }_{1}$ Fm. overlying the Resedimented Messinian Lower Gypsums (Fig. 5(a)). The turbiditic p-ev 1 Fm. includes an ash bed (Fig. 5(b)) present fully along the Apennine foredeep (Fig. 2(b); Roveri et al., 2005) and dated at $5.532 \pm 0.00046 \mathrm{Ma}$ (Cosentino et al., 2013). The pe- $\mathrm{v}_{1}$ Fm. is overlain by the pe- $\mathrm{v}_{2}$ Fm. (62 $\mathrm{m}$ thick) that includes the Colombacci deposits $(23 \mathrm{~m})$ which are in turn overlain by the Zanclean Argille Azzurre (Fig. 5(c)). An angular (erosional) discontinuity separating the p$\mathrm{ev}_{1}$ and $\mathrm{p}-\mathrm{ev}_{2}$ formations was indicated by Bassetti (2000) and Roveri et al. (2001), who referred it to a major reduction in accommodation space linked to the intra-Messinian tectonic phase.

Carloni et al. (1974) recorded planktonic foraminifers from $15 \mathrm{~m}$ below the base of the Colombacci deposits and within them. Casati et al. (1976) performed an oxygen and carbon isotope study on the uppermost $10 \mathrm{~m}$ of the Colombacci Fm. and concluded that salinity was highly variable but that the few foraminifers were allochthonous. Bertini (2006) recorded marine dinoflagellate cysts from the lowermost $\mathrm{p}-\mathrm{ev}_{2} \mathrm{Fm}$., some $40 \mathrm{~m}$ below the base of the Colombacci deposits. All these authors emphasized the ambiguous environmental character of the Colombacci unit. For this reason, the section was re-visited and new samples analysed (Fig. 5(b, c); Popescu et al., 2007). The rare specimens of foraminifers, calcareous nannofossils and dinoflagellate cysts recorded in the upper part of the pe- $\mathrm{v}_{2} \mathrm{Fm}$. (Popescu et al., 2007) were suspected of being reworked because of the assumed inconsistency of brackish ostracods and marine micro-organisms occurring in the same beds (Roveri et al., 2008b). Yet, the unquestionable calcareous nannofossil Ceratolithus acutus recorded in nine samples from the upper p-ev 2 Fm. (i.e., $38 \mathrm{~m}$ below the base of Argille Azzurre) cannot be reworked because the species's first appearance is in the latest Messinian (5.35 Ma; Raffi et al., 2006; Anthonissen and Ogg, 2012). As a consequence, the other planktonic microfossils should be reconsidered. In doing so, Popescu et al. (2007) concluded that these marine proxies indicate that the first influxes of marine waters entered the Apennine foredeep before the beginning of the Zanclean. Bache et al. (2012) defined this marine ingression at 5.36 Ma. Gennari et al. (2008) focussed their study on the Zanclean deposits in which they did not find 
Ceratolithus acutus, even though this species was continuously recorded in the three lowermost Zanclean samples analysed by Popescu et al. (2007). Analyzing calcareous nannoplankton takes longer than usual when recording rare species, particularly at the Messinian-Zanclean transition (Popescu et al., 2008, 2016a).

\subsection{Civitella del Tronto}

Between Ascoli Piceno and Teramo, a very thick section of Messinian post-evaporitic deposits can be observed near Civitella del Tronto (Fig. 6(a)). Located at the foot of the Montagna dei Fiori (Mattei, 1987), the Neogene series mostly comprises the Messinian Laga succession (Fig. 6(a)), the upper part of which (i.e., the Laga $3 \mathrm{Mb}$.) includes the resedimented evaporites (gypsum-arenites) overlain by the $\mathrm{p}-\mathrm{ev}_{1}$ and $\mathrm{p}-\mathrm{ev}_{2}$ formations (Bigi et al., 2009). The Laga $3 \mathrm{Mb}$. can be traced along the ancient road (Strada Provinciale Fondovalle-Salinello) from Civitella del Tronto to Ponzano (Fig. 6(a)). It includes the ash layer present along the entire Apennine foredeep (Fig. 2(b); Roveri et al., 2008a) and dated at Maccarone (see above). The Civitella del Tronto series constitutes the thickest Messinian succession in the deepest part of the Apennine foredeep. The p-ev Fm. is exposed along three segments, respectively $5 \mathrm{~m}, 18 \mathrm{~m}$ and $91 \mathrm{~m}$ thick, separated by covered intervals along the roadcut (Fig. 6(b)). The upper part of the p-ev $\mathrm{Fm}$. comprises $61 \mathrm{~m}$ of thin carbonate beds (the so-called "Colombacci") alternating with sandstone (lower segments I and II and topmost unit of segment III; Fig. 6(b)) and mudrock, dipping at a high angle (Fig. 6(c, d)). The occurrence of Ceratolithus acutus was reported in a calcareous nannoflora found close to the Crocetta Chapel, i.e., in segment III (Luchetti in Brozzetti et al., in press: p. 55). The p-ev2 Fm. is overlain by the Argille Azzurre Fm. (Fig. 6(a)). The occurrence of Ceratolithus acutus in the Colombacci deposits led L. Luchetti (who performed the nannoplankton analysis) to conclude that the return-to-normal marine conditions preceded the Zanclean (Luchetti, in press: fig. 6, p. 48).

The sampled section, which begins approximately $800 \mathrm{~m}$ above the ash layer and some $550 \mathrm{~m}$ below the lowermost Colombacci carbonate bed, runs from $42^{\circ} 46^{\prime} 30.10^{\prime \prime} \mathrm{N}$; $13^{\circ} 41^{\prime} 32.50^{\prime \prime} \mathrm{E}$ to $42^{\circ} 46^{\prime} 41.90^{\prime \prime N}$; 1342'4.10”E (Fig. 6(a)). We analysed the clays in the three segments, mainly in segment III located below the Crocetta Chapel: two samples came from segment I, five samples from segment II, and 62 samples from segment III.

\subsection{Fonte dei Pulcini}


Near Lama dei Peligni, the Fonte dei Pulcini section (4201'51.20”N; $14^{\circ} 10^{\prime} 50.90$ ”E) is located southeast of the Majella mountains (Fig. 2(a)). Here, Primary Lower Gypsums of the Gessoso-Solfifera Fm. are overlain by: (i) p-ev2 clays (240 m thick) designated as Lago Mare deposits on the basis of a rich ostracod fauna (Cosentino et al., 2005) and the occurrence of Paratethyan dinoflagellate cysts including Galeacysta etrusca, and (ii) Zanclean clays (the Taranta Peligna clays equivalent to the Argille Azzurre) including at their base a conglomerate (7 m thick) with the foraminifer Sphaeroidinellopsis (Fig. 7(a, b); Cosentino et al., 2012). At Colle di Votta, on the northern side of the Majella mountains, the thick Gessoso-Solfifera Fm. is cut by the Messinian Erosional Surface and overlain by the usual ash (Sampalmieri et al., 2010), there dated at 5.532 $\pm 0.0074 \mathrm{Ma}$ (Cosentino et al., 2013).

Frequent to abundant calcareous nannofossils and 11 taxa of marine dinoflagellate cysts were found in the $\mathrm{p}-\mathrm{ev}_{2}$ clays from Fonte dei Pulcini (including Ceratolithus sp.) by Cosentino et al. (2012). These authors interpreted the nannofossils as reworked; the dinoflagellates, while not being explicitly judged to be reworked, were not taken into account in the palaeoenvironmental interpretation. Considering the co-occurrence of Paratethyan (brackish) and marine microfossils, we re-visited section A of Cosentino et al. (2005) at the Fonte dei Pulcini locality (i.e., the upper $50 \mathrm{~m}$ of the p-ev 2 Fm.) and took five samples from its uppermost part (Fig. 7(b, c)).

\subsection{Fonte la Casa}

On the northern edge of the Pelagosa palaeo-sill (including the present-day Gargano Peninsula), which probably isolated the Apennine foredeep during the peak of the MSC (Bache et al., 2012), vertical Primary Lower Gypsum and unconformably overlying resedimented gypsum can be observed in several quarries (Fig. 2(b)). Patches of grey clays and yellowish sands lie on top of the Miocene series. They are particularly abundant in the Larino sheet of the 1:100,000 scale geological map of Italy where they are marked "MP" with a Miocene-Pliocene age, thus possibly suggesting a gradual transition from Miocene to Pliocene (Balboni, 1968a). These deposits contain marine macrofossils including the molluscs Pecten, Dentalium, and Cardium (Balboni, 1968b).

In order to clarify the chronostratigraphic position of these 'MP' deposits, we studied two outcrops at the Fonte la Casa hamlet, located between Palmoli and San Buono (Fig. 8(a)), where grey silts rich in mollusc shells (Fig. 8(b-d)) are overlain by yellow sands including some clayey beds (Fig. 8(e-g)). Three samples were taken: one in the grey silts, and two in intercalated clays within the yellowish sands (Fig. 8(b, c-g)). 


\section{Results}

The results of the analyses of calcareous nannofossils and dinoflagellate cysts are provided in Fig. 3 and Table S1 (Appendix A), respectively. Selected taxa are shown in Figs. S1 and S2 (Appendix A).

\subsection{Monticino}

The calcareous nannofossil association from the two sets of samples is taxonomically diverse (Fig. 3). Our record of Discoaster quinqueramus (LAD at 5.59 Ma; Raffi et al., 2006; Anthonissen and Ogg, 2012) in sample 1 has not been considered for dating because it is inconsistent with the age of the base of the p-ev 2 Fm. (5.42 Ma in Roveri et al., 2014; $5.36 \mathrm{Ma}$ in Bache et al., 2012). The dinoflagellate cyst content is rich, largely dominated by the stenohaline species Impagidinium patulum and Nematosphaeropsis labyrinthus, and subordinately by the euryhaline species Lingulodinium machaerophorum (Fig. 9; Appendix A: Table S1). No Paratethyan species were recorded.

\subsection{Maccarone}

The following is a summary of the results of Popescu et al. (2007). The reader is referred to that publication for a more thorough presentation and discussion of the dataset. Calcareous nannofossils are present in sample 1 in the p-ev $\mathrm{Fm}_{2}$., i.e., some $20 \mathrm{~m}$ below the base of the Colombacci deposits (Fig. 9). The biostratigraphic marker Ceratolithus acutus was recorded from sample 5, i.e., in the p-ev 2 Fm., about $16 \mathrm{~m}$ below the base of the Colombacci deposits (Fig. 10).

The lowest occurrence of marine dinoflagellate cysts is at the boundary between the p-ev and $\mathrm{p}-\mathrm{ev}_{2}$ formations, about $38 \mathrm{~m}$ below the base of the Colombacci deposits (Fig. 10; Popescu et al., 2007). Assemblages are dominated by eurhyaline species such as Achomosphaera andalousiensis, Lingulodinium machaerophorum, Operculodinium centrocarpum and selected Spiniferites species (S. bentorii, S. bulloideus, S. ramosus) in the Messinian deposits ( $\mathrm{p}-\mathrm{ev}_{2} \mathrm{Fm}$.), whereas stenohaline species such as Impagidinium patulum and Spiniferites mirabilis prevail in the Zanclean sediments (Argille Azzurre Fm.) (Appendix A: Table S1). A diverse group of Paratethyan dinoflagellate cysts is dominated by Galeacysta etrusca, Impagidinium globosum, Pyxidinopsis psilata, Spiniferites sagittarius, and S. cruciformis (Appendix A: Table S1). A preponderance of marine species in the dinoflagellate cyst record is observed in the Messinian samples 1-5, 12, 34 and 35, and in the Zanclean 
samples 43-45 (Fig. 10). In the other samples a Paratethyan species association prevails (Fig. $10)$.

\subsection{Civitella del Tronto}

Fifteen samples were analysed for calcareous nannofossils (one in segment I, one in segment II, thirteen in segment III); 13 of them provided a nannoflora (Fig. 3). The biostratigraphic marker Ceratolithus acutus was recorded in three samples (48, 62, and 65; Figs. 3, 11). Discoaster quinqueramus was recorded in samples 9, 11, 13, 17, and 20 (Fig. 3). As this species disappeared (at $5.59 \mathrm{Ma}$ ) significantly before the first appearance datum of C. acutus (at 5.35 Ma; Raffi et al., 2006; Anthonissen and Ogg, 2012), first recorded here $19 \mathrm{~m}$ higher in sample 48 (Figs. 3, 11), we consider the specimens of D. quinqueramus to be probably reworked. This option is supported by the age of the ash (5.532 Ma; Cosentino et al., 2013) at

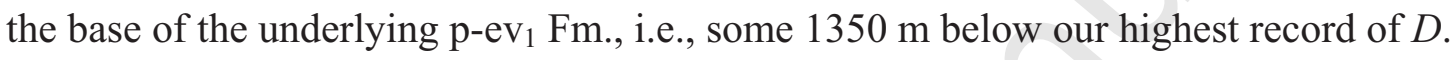
quinqueramus.

A total of 69 samples were analysed for dinoflagellate cysts (two in segment I, six in segment II, 61 in segment III; Fig. 11). Marine dinoflagellate cysts are dominated by the euryhaline species Lingulodinium machaerophorum, Melitasphaeridium choanophorum, Operculodinium centrocarpum and Homotryblioum sp., and by the stenohaline species Spiniferites hyperacanthus (Appendix A: Table S1). Galeacysta etrusca, Impagidinium globosum, Pyxidinopsis psilata, Pontadinium spp., Spiniferites bentorii oblongus, $S$. cruciformis and Spiniferites spp. are prevalent among the Paratethyan dinoflagellate cysts (Appendix A: Table S1). The dinoflagellate cyst assemblages are alternately dominated by marine species and Paratethyan species, with secondary fluctuations (Fig. 11).

\subsection{Fonte dei Pulcini}

The five samples from the Colombacci deposits yielded a diverse calcareous nannoflora, including the biostratigraphic marker Ceratolithus acutus in sample 5 (Figs. 3, 12). This sample also contains specimens of Discoaster quinqueramus that are probably reworked, as also suggested above for Civitella del Tronto.

Marine dinoflagellate cysts (mainly the euryhaline Lingulodinium machaerophorum and the stenohaline Nematosphaeropsis labyrinthus) dominate sample 1 whereas Paratethyan elements (mainly Galeacysta etrusca, Impagidinium globosum, with subordinate Spiniferites bentorii oblongus and Spiniferites spp.) dominate samples 2-5 (Fig. 12; Appendix A: Table $\mathrm{S} 1)$. 


\subsection{Fonte la Casa}

Sample 1 provided a relatively diverse calcareous nannoflora, although the other two samples were barren (Fig. 3). The three samples yielded a dinoflagellate cyst association dominated by marine species (euryhaline: Achomosphaera andalousensis, Homotryblium sp., Lingulodinium machaerophorum, Operculodinium centrocarpum, Spiniferites bulloideus; open marine: S. hyperacanthus). Some Paratethyan species were also recorded (Galeacysta etrusca, Impagidinium globosum, Pyxidinopsis psilata, Spiniferites bentorii oblongus) (Fig. 13; Appendix A: Table S1).

\section{Discussion}

The studied sections provide a fairly wide and diverse micropalaeontological survey of Lago Mare (i.e., Colombacci) deposits in different contexts of the Apennine foredeep: the Maccarone section provides a complete record of the Colombacci deposits, and the Civitella del Tronto section yields a more or less continuous (in part at very high resolution) record of an expanded sedimentary succession. The three other localities give a more limited view of distinct settings within the Apennine foredeep (northern shoreline: Monticino; southern shoreline: Fonte dei Pulcini and Fonte la Casa).

Our palaeoenvironmental data draw attention to the significance of the Lago Mare biofacies in the Apennine foredeep and place it within a precise chronological framework. They show the successive brief incursions of marine waters into the Apennine foredeep, supporting the presence of a structural palaeo-sill which momentarily isolated this basin, as discussed with the help of the offshore seismic profiles. This evidence allows us to propose a new integrated palaeoenvironmental scenario for the Apennine foredeep during the MSC.

\subsection{The Lago Mare, a biofacies horizon}

Paratethyan dinoflagellate cysts are common below the Colombacci deposits. Bertini (2006) first recorded them some $10 \mathrm{~m}$ below the base of the Colombacci deposits at Maccarone, an interval extended to at least $20 \mathrm{~m}$ by Popescu et al. (2007) (Fig. 10). At Civitella del Tronto, Paratethyan dinoflagellate cysts can be found more than $650 \mathrm{~m}$ below the base of the Colombacci deposits. This seriously questions the a-priori accepted equivalence between the Lago Mare and Colombacci deposits (i.e., the "Congerie marls" in the Piedmont Basin; Roveri et al., 2008a). Popescu et al. $(2009,2015)$ and Do Couto et al. (2014) emphasized the importance of Paratethyan dinoflagellate cysts as actual indicators of Lago Mare episodes, 
their occurrence often preceding the Lago Mare biofacies as defined traditionally by ostracods and molluscs. The dinoflagellate cyst record from Maccarone documents the occurrence of the Lago Mare biofacies exclusively within the p-ev2 Fm. (Bertini, 2006; Popescu et al., 2007; Fig. 14). Some "Paratethyan" molluscs from the Po Valley (Esu and Popov, 2012; Harzhauser et al., 2015) and the Sicilian Basin (Harzhauser et al., 2013) have been re-visited and are now interpreted by these specialists as being possibly endemic to the Mediterranean Sea. However, we consider that several disseminations from the Central and Eastern Paratethys may have occurred through the Balkan corridor long before the peak of the MSC (Popescu et al., 2009). Molluscs introduced by successive invasions may have persisted in some ecologically favourable areas as suggested by Do Couto et al. (2014).

Beyond the Apennine foredeep-Po Basin realm, several Mediterranean deposits yield both marine and Paratethyan fossils: the Cava Serredi in Toscana (Carnevale et al., 2006b; Popescu et al., 2009), Arenazzolo deposits at Eraclea Minoa in Sicily (Londeix et al., 2007; Popescu et al., 2009), Casabianda in Corsica (Popescu et al., 2009), Río Mendelín near Malaga in southern Spain (Do Couto et al., 2014), Níjar in southern Spain (Aguirre and SánchezAlmazo, 2004; Do Couto et al., 2014), Lower Rhône Valley (Théziers, Saint-Marcel d'Ardèche, Saint-Restitut, Allex; Do Couto et al., 2014), and the DSDP Hole 134B and ODP Holes 976B and 978A (Popescu et al., 2015). Such interplay of marine and Paratethyan conditions affects the three Lago Mare episodes proposed by Clauzon et al. (2005), Popescu et al. (2009), Do Couto et al. (2014), and Popescu et al. (2015). This interplay can also be extended to several localities from the Paratethys where the permanent regional "Lago Mare" biofacies was interrupted by episodic incursions of Mediterranean marine waters: eastern Pannonian Basin (Central Paratethys; Krašić, Malunje and Krajačići: Popescu et al., 2009), Dacic Basin (Eastern Paratethys; Valea Vacii: Snel et al., 2006; Popescu et al., 2009; Cernat, Hinova: Popescu et al., 2009; Suc et al., 2011; Ticleni: Drivaliari et al., 1999; Badislava: Snel et al., 2006; Stoica et al., 2007), and the Black Sea (Eastern Paratethys, DSDP Site 380: Popescu, 2006; Popescu et al., 2010; Suc et al., 2015; Popescu et al., 2016b).

We emphasize the non-reworked nature of the micro-organisms used in developing our interpretations:

- the robustness of the calcareous nannofossil association is corroborated by the presence of Ceratolithus acutus, the lowest occurrence of which is consistent with the temporal context of the examined deposits. As explained by Popescu et al. (2016), this species cannot result from reworking when it occurs in deposits just preceding the MiocenePliocene boundary. 
- the non-reworked status of the dinoflagellate cyst record is supported by the bright greenish-yellowish colour of specimens when observed in fluorescence light.

As to the debate about the significance of marine microfossils within the Lago Mare deposits, particularly in the Apennine foredeep, our study establishes definitively their status as in-situ elements of the surface microplankton. Our reconstruction of the Lago Mare biofacies in the Apennine foredeep will hopefully stimulate a re-interpretation of the isotopic record for the Colombacci carbonates: despite values of $\delta^{18} \mathrm{O}$ ranging from fresh/brackish to marine conditions, the conclusion reached from these records was that the limestones were deposited in a uniformly brackish palaeoenvironment (Casati et al., 1976; Molenaar and De Feyter, 1985; Bassetti et al., 2004).

\subsection{Attempt in dating marine incursions into the Apennine foredeep at the end of the MSC}

The Colombacci deposits are biochronostratigraphically constrained by the occurrence of the calcareous nannofossil marker Ceratolithus acutus, already indicated at Maccarone by Popescu et al. (2007) (Figs. 3, 10) and at Civitella del Tronto by Luchetti (in Brozzetti et al., in press). At Civitella, we specifically searched for this calcareous nannofossil in samples rich in marine dinoflagellate cysts. This resulted in the documentation of C. acutus in three samples within the Colombacci deposits (Figs. 3, 11). Ceratolithus acutus is a biostratigraphically useful species with a short range (between 5.35 and 5.04 Ma; Raffi et al., 2006; Anthonissen and Ogg, 2012), appearing somewhat before the Messinian-Zanclean boundary at 5.33 Ma (Popescu et al., 2016a). Despite the absence of studied samples in the lowermost part of the $\mathrm{p}-\mathrm{ev}_{2} \mathrm{Fm}$. and hence uncertainty about a possible occurrence of $C$. acutus within this segment, Bache et al. (2012) tentatively regarded the lowest record of $C$. acutus in sample 5 from Maccarone (Figs. 3, 5(b, c), 10) as its lowest occurrence. This constituted potentially a third chronological point (in addition to the ash dated at $5.532 \pm$ 0.00046 Ma and the base of Argille Azzurre at 5.33 Ma) in establishing a cyclostratigraphy for the section based on the pollen record. This approach pointed to an age of 5.36 Ma for the first influx of marine waters into the Apennine foredeep after the peak of the MSC (Bache et al., 2012). At Maccarone, this event marking the boundary between the formations $p-\mathrm{ev}_{1}$ and p-ev 2 is observed some $36 \mathrm{~m}$ below the base of the Colombacci deposits (Fig. 10; Popescu et al., 2007). At Civitella, the lowest record of C. acutus is observed $17 \mathrm{~m}$ above the base of the Colombacci deposits (Fig. 11). Because we searched for calcareous nannofossils in just 13 among 69 samples selected for their rich marine dinoflagellate cyst content (Fig. 3), it is quite possible that we missed the lowest occurrence of $C$. acutus, all the more likely as the lower 
part of the section (segments I and II) has long observation gaps and is dominated by sands unsuitable for nannofossil preservation (Fig. 11). We therefore assume that the records of $C$. acutus at Civitella del Tronto are younger than its first appearance datum at 5.35 Ma. At Fonte dei Pulcini, Cosentino et al. (2005) used the ostracod record to correlate the uppermost $60 \mathrm{~m}$ of Messinian sediments (Fig. 7) with the p-ev 2 Fm., within the $410 \mathrm{~m}$ of deposits overlying the Gessoso-Solfifera Fm. As a consequence, the record of C. acutus in the uppermost studied sample (Figs. 3, 12) cannot represent the lowest occurrence of this species in the Apennine foredeep, and we suggest correlating it with its uppermost record at Civitella del Tronto. The Maccarone section, owing to its high-resolution micropalaeontological records (Bertini, 2006; Popescu et al., 2007) and robust chronology (Bache et al., 2012), serves as the reference framework for Messinian post-evaporitic deposits in the Apennine foredeep (Fig. 14).

The occurrence of marine dinoflagellate cysts within the Colombacci deposits has been shown for several localities including Fonte dei Pulcini (Cosentino et al., 2014), Monticino and Maccarone (Bertini, 2006), but the consequences of such important occurrences have not been adequately emphasized (see Appendix A: Table S1 for comparison). In recent years growing evidence has pointed to a return to normal marine conditions in the Apennine foredeep before deposition of the earliest Zanclean sediments (Crescenti et al., 2002; Luchetti, fig. 6, in Brozzetti et al., in press; Crescenti and Raffi, fig. 12, in Crescenti, in press). The presence of marine fish otoliths in a Colombacci deposit from the Ca' Ciuccio section, north of Ancona (Carnevale et al., 2006a) provides further support for a pre-Zanclean sea-level highstand.

At Maccarone, the lowest occurrence of Ceratolithus acutus is significantly below the Colombacci deposits but within the p-ev 2 Fm. (Popescu et al., 2007). The first evidence of reliable marine dinoflagellate cysts (marked by a sudden improvement in preservation and increase in diversity) including Impagidinium spp., I. aculeatum, Spiniferites ramosus and Lingulodinium machaerophorum (Bertini, 1992), and thus of marine water influx, occurs at the boundary between the $\mathrm{p}-\mathrm{ev}_{1}$ and $\mathrm{p}-\mathrm{ev}_{2}$ formations (Fig. 10; Popescu et al., 2007). Thereafter, palaeoenvironments alternated between marine and brackish based on the successive predominance of marine vs. Paratethyan dinoflagellate cysts. Figs. 10 and 11 present a glimpse of such fluctuations along relatively long records, and Figs. 9, 12 and 13 give a snapshot from short records. Several peaks in the abundance of marine dinoflagellate cysts are observed and numbered from 1 to 4 in the Maccarone section (Fig. 10): 
- peak number 1 marks their lowest occurrence at the boundary between the $\mathrm{p}-\mathrm{ev}_{1}$ and $\mathrm{p}$ $\mathrm{ev}_{2}$ formations (see above);

- peak number 2 just follows the lowest occurrence of calcareous nannofossils and precedes the lowest occurrence of Ceratolithus acutus $18 \mathrm{~m}$ below the base of the Colombacci deposits;

- peak number 3 is less prominent and recorded $7 \mathrm{~m}$ below the base of the Argille Azzurre;

- peak number 4 begins just below the base of the Argille Azzurre.

These peaks of marine dinoflagellate cysts appear to result from at least four marine influxes (Fig. 14):

- the first one shown by Popescu et al. (2007) is dated at 5.36 Ma by Bache et al. (2012);

- the second one, coeval with the first record of C. acutus, is dated at 5.35 Ma (Raffi et al., 2006; Anthonissen and Ogg, 2012);

- the third one, just below the base of the Argille Azzurre, is estimated a little before 5.33 Ma based on correlation of a pollen curve with eccentricity (Bache et al., 2012); - $\quad$ the fourth and last one (peak number 4) is dated near the earliest Zanclean at 5.33 Ma. Several peaks of marine dinoflagellate cysts are also recorded in the Civitella del Tronto section, the most prominent ones belonging to its segment III (Fig. 11). The lowermost peak is located $16 \mathrm{~m}$ below the base of the Colombacci deposits. At this state of knowledge, without neglecting the possibility of more marine influxes in the southern Apennine foredeep, we propose the correlation of this lowermost peak with peak number 2 of Maccarone because this is not the first influx of marine dinoflagellate cysts as shown by Fig. 11 and thus cannot be correlated with peak number 1 of Maccarone. At Civitella del Tronto, the proposed peak number 2 is quite far below our lowest record of C. acutus $(33 \mathrm{~m})$ but it has been discussed above that this record of $C$. acutus probably does not correspond to its lowest occurrence within the Apennine foredeep. We tentatively correlate the overlying peak of marine dinoflagellate cysts with peak number 3 at Maccarone. At Civitella del Tronto, this peak is 45-30 m below the base of the Argille Azzurre whereas this distance is only $7 \mathrm{~m}$ at Maccarone. This is not surprising because the Civitella del Tronto section is expanded, as shown by the difference in thickness of the Colombacci deposits, $58 \mathrm{~m}$ here against $23 \mathrm{~m}$ at Maccarone.

Despite the relatively low number of counted individuals (Appendix A: Table S1), an unquestionably prominent peak of marine dinoflagellate cysts is recorded in sample 1 from Fonte dei Pulcini (Fig. 12). This peak underlies by $12 \mathrm{~m}$ our record of Ceratolithus acutus 
which cannot correspond to the lowest appearance datum of the species because it is located only $1.5 \mathrm{~m}$ below the Zanclean clays (Fig. 12). Accordingly, this peak could correspond to peak numbers 3 or 4 . Considering the distance of $13.5 \mathrm{~m}$ between it and the base of the Zanclean clays, we tentatively correlate it with peak number 3 (Fig. 12) because peak number 4 occurs within the Zanclean clays (not sampled here) as identified at Maccarone (Fig. 10). At Maccarone, peak number 3 is not strongly expressed (Fig. 10) but its increasing representation at Civitella del Tronto (Fig. 11) and then at Fonte dei Pulcini (Fig. 12) can be explained by the geographic location of these localities, being progressively closer to the source of marine waters.

Sample 1 from Fonte la Casa shows a high percentage of marine dinoflagellate cysts; samples 2 and 3 are very poor but show the same tendency (Fig. 13). Sample 1 and the cluster of samples 2 and 3 could belong to the same peak of marine dinoflagellate cysts or to two successive peaks, as they are separated by a stratigraphic distance of $22 \mathrm{~m}$. In the absence of any biostratigraphic assignment based on the calcareous nannofossils (Fig. 3), their correlation to a specific peak is left undetermined (Fig. 13).

Finally, at Monticino, the exclusive presence of marine dinoflagellate cysts in all samples (Appendix A: Table S1) contrasts with the poor record of dinoflagellate cysts (while mostly marine) indicated for these sediments by Bertini (1992, 2006) (Fig. 9). As the calcareous nannoflora is not discriminating (Fig. 3), we cannot easily correlate this optimum in marine dinoflagellate cysts to any specific peak recorded at Maccarone or Civitella del Tronto (Figs. 10, 11). This in particular holds for samples 6-8 from deep mudstones filling a karstic fissure. However, the dinoflagellate cyst assemblages of samples 1-5 (Appendix A: Table S1) from sediments immediately below the Argille Azzurre might be tentatively attributable to peak number 4 considering its strong expression (Fig. 9). As almost the same dinoflagellate cyst assemblages are recorded within the karstic fissure $n^{\circ}$ 8bis (Appendix A: Table S1, samples 6-8), this sedimentary infilling could therefore belong to the same incursion of marine waters (Fig. 9), which would imply a wider geographic extent for this incursion than for previous ones.

The oldest of these influxes of marine waters reached the northern Apennine foredeep significantly before the beginning of the Zanclean (5.33 Ma). Its timing has been estimated at 5.36 Ma from the Maccarone section by Bache et al. (2012) (Fig. 14), i.e., some 100 kyrs later than the catastrophic reflooding of the Mediterranean Basin proposed at 5.46 Ma by the same authors. These arguments lead us to consider that the Apeninne foredeep was disconnected from the Ionian Sea (i.e., from the entire Mediterranean Sea) between 5.46 and 5.36 Ma. 


\subsection{Existence of a composite palaeo-sill in the Gargano-Pelagosa region}

Miljush (1973), Corselli and Grecchi (1984), and then Clauzon et al. (1997) considered the presence of a palaeo-sill isolating the Apennine foredeep from the Ionian Basin during the second step of the MSC (5.60-5.46 Ma) as being essential to explain the deposition of the deep freshwater levels of the $\mathrm{p}-\mathrm{ev}_{1} \mathrm{Fm}$. Such freshwater conditions are particularly evidenced in the Maccarone section by the absence of marine micro-organisms (Carloni et al., 1974; Popescu et al. 2007; Sampalmieri et al., 2010) and by ${ }^{87} \mathrm{Sr} /{ }^{86} \mathrm{Sr}$ data in the southern Apennine foredeep (Matano et al., 2005).

The location and origin of this palaeo-sill are debated, with a location first proposed in the area of the Gargano Peninsula (Miljush, 1973; Corselli and Grecchi, 1984), then at the present-day Otranto sill (Clauzon et al., 2005), and finally in the area of the present-day Pelagosa sill (Bache et al., 2012) (Fig. 15). Palinspastic reconstructions published by Vai (2016) also consider the occurrence of a Messinian sill in this area. However, no seismic profile from the Adriatic Sea was shown to support the hypothesis of a palaeo-sill. In fact, the palaeo-sill location is the result of different processes inherited from the Mesozoic sedimentary evolution and post-Mesozoic geodynamic history of the Adria plate. This morphological high is proposed to have existed since the mid-Oligocene and to have emerged at each significant sea-level fall from this time, hence serving periodically as a land bridge for mammal migration (Patacca et al., 2008).

For the offshore part of the Gargano-Pelagosa region illustrated by line drawings of interpreted seismic profiles (Fig. 16), some dissymmetry is observed between the Central and South Adriatic domains. The latter is associated with the development of Oligocene-Miocene and Pliocene-Quaternary sedimentary sequences in the Mesozoic Ionian basin. Conversely, along the Dinarid chain and in the Central Adriatic domain, the top of the Mesozoic platform and Paleogene structures show few if any Miocene and Pliocene-Quaternary sedimentary sequences. The Messinian surfaces and sedimentary units are no exception to these observations. The region of the Apulian platform - of which most of the Gargano Peninsula is made - is thus the best candidate for the location of the barrier responsible for the relative isolation of the Apennine foredeep during Neogene time.

Some onshore lines of evidence also support this hypothesis. Southeast of the GarganoApulian platform along the Apennine chain, a strong dissymmetry can be observed for the Messinian deposits overlying the Resedimented Lower Gypsums: $\mathrm{p}-\mathrm{ev}_{1}$ and $\mathrm{p}-\mathrm{ev}_{2}$ formations on the northern side, and the Messinian Laga Basin and deltaic deposits on the southern side 
(Fig. 2(b)). Both domains are overlain by Zanclean marine clayey sediments (Roveri et al., 2008a; Matano, 2007). The processes related to this difference are clearly of geodynamic nature, in which sedimentary and subsidence dynamics are linked, and bound either by the successive compressive phases along the chain (Bertotti et al., 2001; Vezzani, 2010) and/or by possible tearing of the plunging panel (Ascione et al., 2012). Whatever the dominant processes, the Messinian event has also been linked to a major regional compressive phase along the Apennine chain (Ricchi Lucchi, 1986; Bigi et al., 1999; Roveri et al., 2001; Roveri and Manzi, 2006). This phase controlled the development and accommodation of the Messinian Apennine foredeep north of the Gargano Peninsula and uplift around the Gargano Peninsula and in the south Apennine region, as observed by seismic profiles (Bertotti et al., 2001) and field studies along the South Apennine chain (Matano et al., 2005; Vezzani et al., 2010). This uplift is also seen in the field with tilting of the Primary Lower Gypsums (Marabini and Vai, 1985) to verticality near the Gargano Peninsula (Ciaranfi et al., 1976; Matano, 2007; Senatore et al., 2012) (Fig. 2(b)).

\subsection{Towards an integrated MSC palaeoenvironmental model for the Apennine foredeep}

The Lago Mare biofacies (including Paratethyan dinoflagellate cysts) documented in the Apennine foredeep refers to Lago Mare 3, i.e., the youngest of the three Lago Mare episodes distinguished by Clauzon et al. (2005), Do Couto et al. (2014), and Popescu et al. (2015), having occurred after the marine reflooding of the Mediterranean Basin at 5.46 Ma (Bache et al., 2012). Lago Mare 3 is known from many places in the Mediterranean (Do Couto et al., 2014). A reasonable possibility exists therefore that the first inflow of marine waters into the Apennine foredeep at 5.36 Ma seeded this basin with Paratethyan organisms (dinoflagellates, larvae of ostracods and molluscs - dreissenids and limnocardiids) transported by surface waters. They could have developed in several favourable areas where salinity was lower than that of the Mediterranean (Fig. 14). In such places, the Paratethyan organisms documented by several researchers (Gillet, 1968; Colalongo et al., 1976; Bellagamba, 1978; Esu and Taviani, 1989; Bassetti et al., 2003; Bertini, 2006; Faranda et al., 2007; Gliozzi et al., 2007; Popescu et al., 2007; Esu and Girotti, 2008) could have proliferated during time intervals separating the successive brief inflows of marine waters, and they finally disappeared after the fourth (Fig. 14).

The data obtained here from the localities of Monticino, Civitella del Tronto, Fonte dei Pulcini and Fonte la Casa are compatible with those previously acquired along the thicker Maccarone stratigraphic section (Popescu et al., 2007). By integrating all available 
information on the Apennine foredeep and Po Basin, it is now possible to reconstruct the palaeogeographic evolution of the region and its relationships with the Ionian Basin (Fig. 15(c)), which completes and clarifies the reconstruction proposed by Scarselli et al. (2007). A palaeo-cross-section CD is drawn from the northern Po Basin to the Ionian Basin (Fig. 15(a)) on the basis of the palaeo-topography drawn in Fig. 2(b) that can be compared to the presentday cross-section AB (Fig. 15(b)).

Before 5.97 Ma, i.e., before the onset of the MSC (Manzi et al., 2013), all the basins were connected and filled by marine waters up to the southwestern margin of the Po Basin, i.e., the Piedmont Basin (Sturani, 1973; Dela Pierre et al., 2011, 2012) (Fig. 15(c)). From 5.97 to 5.60 Ma, the minor fall in sea level that affected the Mediterranean Sea (Clauzon et al., 2015a) caused deposition of the Primary Lower Gypsums in the shallow marginal basins (e.g., Po Basin, outer Apennine foredeep; Fig. 2; Selli, 1973; Roveri et al., 2008a; Lugli et al., 2010; Manzi et al., 2013). This episode is the first step of the MSC as defined by Clauzon et al. (1996). Evaporitic deposits of this episode were interrupted by clay intercalations indicating marine incursions into the shallow basins and high sea level reconnection at the Mediterranean scale, as mainly evidenced by fish remains (Sturani, 1973; Fontes et al., 1987; Carnevale et al., 2008) and dinoflagellate cysts (Bertini, 2006).

The huge Mediterranean Sea-level drawdown that characterized the second (paroxysmal) step of the MSC occurred at 5.60 Ma (Clauzon et al., 1996). Bache et al. (2012, 2016) proposed a succession of events in the central Mediterranean basins during the time interval covering the peak of the crisis and the marine reflooding of the Mediterranean Basin up to the earliest Zanclean (i.e., 5.60-5.33 Ma). In the Adriatic domain, several coeval and brief events occurred at the beginning of this time-interval, probably consistently with other periMediterranean areas. Basin-floor uplift caused by sudden isostatic rebound at 5.60 Ma has been estimated at $c a$. 1,000 $\mathrm{m}$ in the Ionian Sea facing southern Calabria (DeCelles and Cavazza, 1995), a value not contradicted by field data in the Eastern Pyrenees (Clauzon et al., 2015b). The Gargano-Pelagosa palaeo-sill, as we call it, may have been significantly uplifted, thus turning the Apennine and Po basins into an isolated perched area as already proposed by Corselli and Grecchi (1985) and Cita and Corselli (1990) (Fig. 15(c)). Subaerial erosion took place simultaneously, forced by both the sea-level drop, active also in the margins of the Apennine foredeep, and the isostatically-driven land uplift (Fauquette et al., 2015b). The resulting Messinian Erosional Surface is obvious offshore on both sides of the palaeo-sill (Fig. 16) and off the Po Plain (Rossi et al., 2015). Subaerial erosion caused changes in the drainage network and/or its entrenchment (Scarselli et al., 2007), and the formation of karstic 
cavities within the Primary Lower Gypsums (De Waele and Pasini, 2013); it is hypothesized to be at the origin of the lakes in the northern Po Plain (Bini et al., 1978; Cita and Corselli, 1990). At Monticino, the Messinian Erosional Surface is particularly well exposed through its two aerial (Fig. 4(b, d)) and karstic (Fig. 4(e-g)) expressions. The occurrence of a land bridge during the peak of the MSC is evoked to explain the distribution of fossil micromammals (De Giuli et al., 1987) and living plants (Musacchio et al., 2006; Bellusci et al., 2010) on both sides of the Adriatic Sea and northern Ionian Sea.

Freshwater, probably supplied in abundance by the surrounding uplands (Alps: Fauquette et al., 2015a; Apennines: Fauquette et al., 2015b), filled the Apennine foredeep and Po Basin where high levels persisted during the lowered Mediterranean Sea level (5.60-5.46 Ma). During this phase, the Resedimented Lower Gypsums (resulting from the erosion of the Primary Lower Gypsums) were deposited in subaqueous environments as coarse material in marginal areas (Corselli and Grecchi, 1984; Dela Pierre et al., 2007) or as gypsarenites in turbiditic contexts in the foredeep (Bigi et al., 1999; Manzi et al., 2005; Fig. 2(b)).

Bache et al. (2012) proposed an age of 5.46 Ma for the marine reflooding of the Mediterranean, which probably occurred significantly before the beginning of the Zanclean Stage (5.33 Ma) based on many lines of evidence (Cavazza and DeCelles, 1998; Cornée et al., 2006; Bache et al., 2012; Popescu et al., 2015). However, marine waters did not immediately enter the Apeninne foredeep as observed at Maccarone where their arrival, located at the boundary between the $\mathrm{p}-\mathrm{ev}_{1}$ and $\mathrm{p}-\mathrm{ev}_{2}$ formations (Popescu et al., 2007), has been precisely dated at 5.36 Ma (Bache et al., 2012).

From 5.36 Ma, marine waters overflowed the palaeo-sill and penetrated the Apennine foredeep, transporting in after a short delay the Paratethyan elements (dinoflagellate cysts, larvae of molluscs and ostracods; Fig. 14; Popescu et al., 2007). At least four overflows of marine waters are potentially identified in this work (Fig. 14), which possibly later invaded the Po Basin (Channell et al., 1994; Mary et al., 1999; Sprovieri et al., 2007; Violanti et al., 2011). This process was probably forced first by the isostatic response of the palaeo-sill linked to the Apennine deformation phase and/or to the reflooding of the Mediterranean Basin, and then by the continuous global sea-level rise after 5.33 Ma (Gorini et al., 2014). Bassetti (2000) and Roveri et al. (2001) defined an unconformity separating the p-ev $v_{1}$ and p$\mathrm{ev}_{2}$ formations. They described the marine transgression following this erosional event as being "driven by a generalized subsidence following the acme of the intra-Messinian tectonic phase" (Roveri et al., 2001). At Maccarone, this transgression is marked by a sudden increase in Pinus within the pollen record (Bertini, 2006). Because Pinus produces bisaccate pollen 
favoured by water transport (Beaudouin et al., 2007), its increased abundance is interpretable as resulting from a retreating palaeo-shoreline during sea-level rise (Popescu et al., 2007).

Despite its depth, the Apennine foredeep evolved differently from the central Mediterranean basins during the peak of the MSC and thus cannot be proposed as a reference for the entire Mediterranean during this event, contrary to the assertion of Roveri et al. $(2001,2014)$. Lastly, the transition from the Colombacci deposits to the Argille Azzurre, as that from the Arenazzolo to Trubi in Sicily (Bache et al., 2012), must be regarded as a significant step in the continuous global sea-level rise after the late Messinian glacial period in the Antarctic (Gorini et al., 2014).

\section{Conclusion}

This study provides new evidence that the Lago Mare deposits, particularly those from the Apennine foredeep and probably the entire Po Basin, are more complex than usually considered. They are not characterized merely by brackish conditions but by alternating brief marine and longer brackish episodes. The first inflow carried marine dinoflagellates followed by Paratethyan ones over the Gargano-Pelagosa palaeo-sill into the isolated Apennine and Po basins. There, the marine species survived briefly and the brackish Paratethyan species persisted until the following marine influx. Four comparable marine phases have been identified between 5.36 and 5.33 Ma. Their recognition, based on both calcareous nannofossil and dinoflagellate cyst contents, constitutes an efficient way to discriminate between the $\mathrm{p}-\mathrm{ev}_{1}$ and $\mathrm{p}-\mathrm{ev}_{2}$ formations, as well as a potential tool for stratigraphic correlation within the latter. The idea of a strict one-to-one correlation between the Colombacci deposits and the Lago Mare facies in the Piedmont Basin must be seriously re-evaluated.

In addition to providing an innovative way of correlating stratigraphically the Messinian post-evaporitic sections within the Apennine foredeep, this integrated study of calcareous nannofossils and dinoflagellate cysts results in a refined palaeogeographic reconstruction of the region at the end of the MSC. The specific evolution of the Apennine foredeep as an isolated perched basin during most of the second step of the MSC disqualifies this area as reference for the peak of the crisis for the entire Mediterranean Basin. Conversely, this work gives substance to the scenario postulated by Corselli and Grecchi (1984) and Cita and Corselli (1990). Integrated micropalaeontological analyses and offshore-onshore field investigations support the notion of a palaeo-sill in the area of the Gargano Peninsula and, offshore, of the present-day Pelagosa sill as hypothesized by Miljush (1973). Finally, this 
work provides additional evidence that the marine reflooding of the Mediterranean Basin after the MSC significantly preceded the beginning of the Zanclean.

\section{Acknowledgments}

We particularly thank Prof. G.B. Vai, Director of the Monticino Geopark, for permitting our sampling. F. Lirer contributed to the sampling trips at Civitello del Tronto. The TerMex Program (MISTRALS) provided significant financial support through the project AFAME for micropalaeontological analyses and two field trips to Civitella del Tronto. The other field trips were supported by the CNRS-INSU 'SYSTER' and 'Actions Marges' programs (projects 'Mouvements verticaux' and 'MEDOCC'), and by IFREMER. A scholarship to R. Pellen was provided by the 'Laboratoire d'Excellence' LabexMER (ANR-10-LABX-19), a French government-funded project under the program 'Investissements d'Avenir' and cofunded by a grant from the Regional Council of Brittany. It was further supported by IFREMER, CNRS and UBO with additional support from the French 'Actions Marges' program and the GRI Méditerranée (Groupement Recherche et Industrie TOTAL-UPMC). TOTAL is acknowledged for permission to publish the line drawings of seismic profiles NOSE05 and NOSE07. We are particularly grateful to three anonymous reviewers whose constructive comments led to significant improvements to our manuscript.

\section{Appendix A. Supplementary information}

Supplementary information (Figs. S1 and S2 and Table S1) associated with this article can be found, in the online version, at:

\section{References}

Aguirre, J., Sánchez-Almazo, I.M., 2004. The Messinian post-evaporitic deposits of the Gafares area (Almeria-Níjar basin, SE Spain). A new view of the "Lago-Mare" facies. Sedimentary Geology 168, 71-95.

Albouy, E., Casero, P., Eschard, R., Rudkiewicz, J.-L., 2002. Tectonics and sedimentation in the central Apennines. $81^{\text {st }}$ Meeting of the Italian Geological Society, Turin, abstracts.

Anthonissen, D.E., Ogg, J., 2012. Cenozoic and Cretaceous Biochronology of Planktonic Foraminifera and Calcareous Nannofossils, in: Gradstein, F., Ogg, J., Schmitz, M., Ogg, G. (Eds.), The Geological Time Scale 2012. Elsevier, Amsterdam, Appendix 3, pp. $1083-1127$. 
Artoni, A., 2013. The Pliocene-Pleistocene stratigraphic and tectonic evolution of the Central sector of the Western Periadriatic Basin of Italy. Marine and Petroleum Geology 42, 82-106.

Ascione, A., Ciarcia, S., Di Donato, V., Mazzoli, S., Vitale, S., 2012. The PlioceneQuaternary wedge-top basins of southern Italy: an expression of propagating lateral slab tear beneath the Apennines. Basin Research 24, 456-474.

Bache, F., Gargani, J., Suc, J.-P., Gorini, C., Rabineau, M., Popescu, S.-M., Leroux, E., Do Couto, D., Jouannic, G., Rubino, J.-L., Olivet, J.-L., Clauzon, G., Dos Reis, A.T., Aslanian, D., 2015. Messinian evaporite deposition during sea level rise in the Gulf of Lions (Western Mediterranean). Marine and Petroleum Geology 66, 262-277.

Bache, F., Popescu, S.-M., Rabineau, M., Gorini, C., Suc, J.-P., Clauzon, G., Olivet, J.-L., Rubino, J.-L., Melinte-Dobrinescu, M.C., Estrada, F., Londeix, L., Armijo, R., Meyer, B., Jolivet, L., Jouannic, G., Leroux, E., Aslanian, D., Dos Reis, A.T., Mocochain, L., Dumurdžanov, N., Zagorchev, I., Lesić, V., Tomić, D., Çağatay, M.N., Brun, J.-P., Sokoutis, D., Csato, I., Ucarkus, G., Çakir, Z., 2012. A two-step process for the reflooding of the Mediterranean after the Messinian Salinity Crisis. Basin Research 24, $125-153$.

Balboni, A., 1968a. 154 Larino sheet. Carta geologica d'Italia alla scala 1:100.000. Servizio Geologico d'Italia, Rome.

Balboni, A., 1968b. VII. 154 Larino sheet. Note illustrative della carta geologica d'Italia alla scala 1:100.000. Servizio Geologico d'Italia, Rome.

Bassetti, M.A., 2000. Stratigraphy, sedimentology and paleogeography of Upper Messinian ("'post-evaporitic") deposits in Marche area (Apennines, Central Italy). Memorie di Scienze Geologiche, Università di Padova 52, 319-349.

Bassetti, M.A., Manzi, V., Lugli, S., Roveri, M., Longinelli, A., Ricci Lucchi, F., Barbieri, M., 2004. Paleoenvironmental significance of Messinian post-evaporitic lacustrine carbonates in the northern Apennines, Italy. Sedimentary Geology 172, 1-18.

Bassetti, M.A., Miculan, P., Ricci Lucchi, F., 2003. Ostracod faunas and brackish-water environments of the late Messinian Sapigno section (northern Apennines, Italy). Palaeogeography, Palaeoclimatology, Palaeoecology 198, 335-352.

Beaudouin, C., Suc, J.-P., Escarguel, G., Arnaud, M., Charmasson, S., 2007. The significance of pollen signal in present-day marine terrigenous sediments: The example of the Gulf of Lions (western Mediterranean Sea). Geobios 40, 159-172.

Bellagamba, M., 1978. Gli “'strati a Congerie’” di Capanne di Bronzo (Pesaro) del 
Messiniano terminale e deduzioni paleoambientali. Acta Naturalia dell'Ateneo Parmense 14, 207-222.

Bellusci, F., Musacchio, A., Palermo, A.M., Pellegrino, G., 2010. Exploring the history of Serapias politisii (Orchidaceae), a narrow endemic on the opposite coasts of the Otranto channel: insights from molecular investigations. Botanical Journal of the Linnean Society $162,572-580$.

Bertini, A., 1992. Palinologia ed aspetti ambientali del versante adriatico dell'Appennino centro-settentrionale durante il Messiniano e lo Zancleano. Ph.D. thesis, University of Florence (unpubl.).

Bertini, A., 1994. Palynological investigations on Upper Neogene and Lower Pleistocene sections in central and northern Italy. Memorie della Società Geologica Italiana 48, $431-443$

Bertini, A., 2006. The Northern Apennines palynological record as a contribute for the reconstruction of the Messinian palaeoenvironments. Sedimentary Geology 188-189, 235-258.

Bertotti, G., Picotti, V., Chilovi, C., Fantoni, R., Merlini, S., Mosconi, A., 2001. Neogene to Quaternary sedimentary basins in the south Adriatic (Central Mediterranean): Foredeeps and lithospheric buckling. Tectonics 20, 771-787.

Bigi, S., Calamita, F., Cello, G., Centamore, E., Deiana, G., Paltrinieri, W., Pierantoni, P.P., Ridolfi, M., 1999. Tectonics and sedimentation within a Messinian foredeep in the Central Apennines, Italy. Journal of Petroleum Geology 22, 5-18.

Bigi, S., Milli, S., Corrado, S., Casero, P., Aldega, L., Botti, F., Moscatelli, M., Stanzione, O., Falcini, F., Marini, M., Cannata, D., 2009. Stratigraphy, structural setting and burial history of the Messinian Laga basin in the context of Apennine foreland basin system. Journal of Mediterranean Earth Sciences 1, 61-84.

Bini, A., Cita, M.B., Gaetani, M., 1978. Southern Alpine lakes - Hypothesis of an erosional origin related to the Messinian entrenchment. Marine Geology 27, 271-288.

Brozzetti, F., Boncio, P., Lavecchia, G., in press. 339 Teramo sheet. Note illustrative della carta geologica d'Italia alla scala 1:50.000. Servizio Geologico d'Italia, Rome. (http://www.isprambiente.gov.it/Media/carg/note_illustrative/339_Teramo.pdf).

Carloni, G.C., Francavilla, F., Borsetti, A.M., Cati, F., D’Onofrio, S., Mezzetti, R., Savelli C., 1974. Ricerche stratigrafiche sul limite Miocene-Pliocene nelle Marche centromeridionali. Giornale di Geologia 39, ser. 2, 363-392.

Carnevale, G., Caputo, D., Landini, W., 2006a. Late Miocene fish otoliths from the 
Colombacci Formation (Northern Apennines, Italy): Implications for the Messinian

'Lago-mare' event. Geological Journal 41, 537-555.

Carnevale, G., Caputo, D., Landini, W., 2008. A leerfish (Teleostei, Carangidae) from the

Messinian evaporite succession of the Vena del Gesso basin (Romagna, Apennines,

Italy): palaeogeographical and palaeoecological implications. Bollettino della Società

Paleontologica Italiana 47, 169-176.

Carnevale, G., Landini, W., Sarti, G., 2006b. Mare versus lago-mare: marine fishes and the

Mediterranean environment at the end of the Messinian Salinity Crisis. Journal of the

Geological Society, London 163, 75-80.

Casati, P., Bertozzi, P., Cita, M.B., Longinelli, A., Damiani, V., 1976. Stratigraphy and

paleoenvironment of the Messinian "Colombacci” Formation in the Periadriatic trough.

A pilot study. Memorie della Società Geologica Italiana 16, 173-195.

Castradori, D., 1998. Calcareous nannofossils in the basal Zanclean of the Eastern

Mediterranean Sea: remarks on palaeoceanography and sapropel formation, in:

Robertson, A.H.F., Emeis, K.C., Richter, C., Camerlenghi, A. (Eds.), Proceedings of the

Ocean Drilling Program, Scientific Results 160, U.S. Government Printing Office,

Washington, pp. 113-123.

Cavazza, W., DeCelles, P.G., 1998. Upper Messinian siliciclastic rocks in southeastern

Calabria (southern Italy): palaeotectonic and eustatic implications for the evolution of

the central Mediterranean region. Tectonophysics 298, 223-241.

Centamore, E., Pambianchi, G., Deiana, G., Calamita, F., 1991. Ambiente fisico delle

Marche : Geologia - Geomorfologia - Idrogeologia. Map at scale 1:1000,000.

S.E.L.C.A., Florence.

Channell, J.E.T., Poli, M.S., Rio, D., Sprovieri, R., Villa, G., 1994. Magnetic stratigraphy and biostratigraphy of Pliocene "argille azzurre" (Northern Apennines, Italy).

Palaeogeography, Palaeoclimatology, Palaeoecology 110, 83-102.

Ciaranfi, N., Dazzaro, L., Pieri, P., Rapisardi, L., Sardella, A., 1976. Preliminary description of some Messinian evaporitic facies along the Abruzzi-Molise boundary. Memorie della Società Geologica Italiana 16, 251-260.

Cita, M.B., Corselli, C., 1990. Messinian paleogeography and erosional surfaces in Italy: an overview. Palaeogeography, Palaeoclimatology, Palaeoecology 77, 67-82.

Clauzon, G., Le Strat, P., Duvail, C., Do Couto, D., Suc, J.-P., Molliex, S., Bache, F., Besson, D., Lindsay, E.H., Opdyke, N.D., Rubino, J.-L., Popescu, S.-M., Haq, B.U., Gorini, C., 
2015b. The Roussillon Basin (S. France): A case-study to distinguish local and regional events between 6 and 3 Ma. Marine and Petroleum Geology 66, 18-40.

Clauzon, G., Rubino, J.-L., Casero, P., 1997. Regional modalities of the Messinian Salinity

Crisis in the framework of two phases model. Neogene basins of the Mediterranean region: controls and correlation in space and time, R.C.M.N.S. Interim-Colloquium, Catania, Program and Abstracts, pp. 44-46.

Clauzon, G., Suc, J.-P., Do Couto, D., Jouannic, G., Melinte-Dobrinescu, M.C., Jolivet, L., Quillévéré, F., Lebret, N., Mocochain, L., Popescu, S.-M., Martinell, J., Doménech, R., Rubino, J.-L., Gumiaux, C., Warny, S., Bellas, S.M., Gorini, C., Bache, F., Rabineau, M., Estrada, F., 2015a. New insights on the Sorbas Basin (SE Spain): The onshore reference of the Messinian Salinity Crisis. Marine and Petroleum Geology 66, 71-100. Clauzon, G., Suc, J.-P., Gautier, F., Berger, A., Loutre, M.-F., 1996. Alternate interpretation of the Messinian salinity crisis: Controversy resolved? Geology 24, 363-366.

Clauzon, G., Suc, J.-P., Popescu, S.-M., Marunteanu, M., Rubino, J.-L., Marinescu, F., Melinte, M.C., 2005. Influence of the Mediterranean sea-level changes over the Dacic Basin (Eastern Paratethys) in the Late Neogene. The Mediterranean Lago Mare facies deciphered. Basin Research 17, 437-462.

Colalongo, M.L., 1988. Planktic foraminifer biostratigraphy, with remarks on benthic foraminifers and ostracodes (Monticino Quary, Faenza), in: De Giuli, C., Vai, G.B. (Eds.), Fossil vertebrates in the Lamone Valley, Romagna Apennines. Field trip Guidebook. Università di Bologna, Università di Firenze, Comune di Faenza, pp. 5354.

Colalongo, M.L., Cremonini G., Farabegoli E., Sartori, R., Tampieri, R., Tomadin, L., 1976. Palaeoenvironmental study of the "Colombacci" Formation in Romagna (Italy): The Cella section. Memorie della Società Geological Italiana 16, 197-216.

Compagnoni, B., Galluzzo, F., Capotolti, F., Bonomo, R., D’Ambrogi, C., Di Stefano, R., Graziano, R., Pampaloni, L., Pantaloni, M., Ricci, V., 2005. Carta geologica d'Italia (scale 1:1,250,000) Servizio Geologico d'Italia, S.E.L.C.A., Florence.

Corbí, H., Soria, J., Lancis, C., Giannetti, A., Tent-Manclús, J.E., Dinarès-Turell, J., 2016. Sedimentological and Paleoenvironmental scenario before, during, and after the Messinian Salinity Crisis: The San Miguel de Salinas composite section (western Mediterranean). Marine Geology 379, 246-266.

Cornée, J.-J., Ferrandini, M., Saint Martin, J.P., Münch, P., Mouladde, M., Ribaud-Laurenti, A., Roger, S., Saint Martin, S., Ferrandini, J., 2006. The late Messinian erosional 
surface and the subsequent reflooding in the Mediterranean: New insights from the Melilla-Nador basin (Morocco). Palaeogeography, Palaeoclimatology, Palaeoecology $230,129-154$.

Corradini, D., Biffi, U., 1988. Etude des Dinokystes à la limite Messinien-Pliocène dans la coupe Cava Serredi, Toscane, Italie. Bulletin des Centres de Recherche ExplorationProduction Elf-Aquitaine 12(1), 221-236.

Corselli, C., Grecchi, G., 1984. The passage from hypersaline to hyposaline conditions in the Mediterranean Messinian: Discussion of the possible mechanisms triggering the "Lago Mare" facies. Paléobiologie continentale 14(2), 225-239.

Cosentino, D., Bertini, A., Cipollari, P., Florindo, F., Gliozzi, E., Grossi, F., Lo Mastro, S., Sprovieri, M., 2012. Orbitally forced paleoenvironmental and paleoclimate changes in the late postevaporitic Messinian of the central Mediterranean Basin. Geological Society of America Bulletin 124, 499-516.

Cosentino, D., Buchwaldt, R., Sampalmieri, G., Iadanza, A., Cipollari, P., Schildgen, T.F., Hinnov, L.A., Ramezani, J., Bowring, S.A., 2013. Refining the Mediterranean "Messinian gap" with high-precision U-Pb zircon geochronology, central and northern Italy. Geology 43, 323-326.

Cosentino, D., Cipollari, P., Lo Mastro, S., Giampaolo, C., 2005. High-frequency cyclicity in the latest Messinian Adriatic foreland basin: Insight into palaeoclimate and palaeoenvironments of the Mediterranean Lago-Mare episode. Sedimentary Geology $178,31-53$.

Cremonini, G., D’Onofrio, S., Rabbi, E., Boattinio, R., Fabbri, P., Giorgi, G., 1973. Ricerche paleoambientali in una sezione mio-pliocenica dell'Appennino romagnolo. Giornale di Geologia 39(1), ser. 2, 253-270.

Crescenti, U., 1975. Sul substrato pre-pliocenico dell'avanfossa appenninica dalle Marche allo Jonio. Bollettino della Società Geologica Italiana 94, 583-634.

Crescenti, U., Biondi, R., Raffi, I., Rusciadelli, G., 2002. The S. Nicolao section (Montagna della Maiella): a reference section for the Miocene-Pliocene boundary in the Abruzzi area. Bollettino della Società Geologica Italiana spec. issue 1, 509-516.

Crescenti, U., Raffi, I. in press. VI. Cenni sugli biostratigrafici e cronostratigrafici adottati.

361 Chieti sheet. Note illustrative della carta geologica d'Italia alla scala 1:50,000.

Servizio Geologico d'Italia, Rome, pp. 34-38.

(http://www.isprambiente.gov.it/Media/carg/note_illustrative/361_Chieti.pdf). 
De Giuli, C., Masini, F., Torre, D., Benericetti, A., Costa, G.P., Fosella, M., Sami, M., 1988. The mammal fauna of Monticino Quarry, in: De Giuli, C., Vai, G.B. (Eds.), Fossil vertebrates in the Lamone Valley, Romagna Apennines. Field trip Guidebook. Università di Bologna, Università di Firenze, Comune di Faenza, pp. 65-69.

De Giuli, C., Masini, F., Valleri, G., 1987. Paleogeographic evolution of the Adriatic area since Oligocène to Pleistocene. Rivista Italiana di Paleontologia e Stratigrafia 93, 109 126.

De Waele, J., Pasini, G., 2013. Intra-messinian gypsum palaeokarst in the Northern Apennines and its palaeogeographic implications. Terra Nova 25, 199-205.

DeCelles, P.G., Cavazza, W., 1995. Upper Messinian conglomerates in Calabria, southern Italy: response to orogenic wedge adjustment following Mediterranean sea-level changes. Geology 25, 775-778.

Dela Pierre, F., Bernardi, E., Cavagna, S., Clari, P., Gennari, R., Irace, A., Lozar, F., Lugli, S., Manzi, V., Natalicchio, M., Roveri, M., Violanti, D., 2011. The record of the Messinian salinity crisis in the Tertiary Piedmont Basin (NW Italy): the Alba section revisited. Palaeogeography, Palaeoclimatology, Palaeoecology 310, 238-255.

Dela Pierre, F., Clari, P., Bernardi, E., Natalicchio, M., Costa, E., Cavagna, S., Lozar, F., Lugli, S., Manzi, V., Roveri, M., 2012. Messinian carbonate-rich beds of the Tertiary Piedmont Basin (NW Italy): microbially-mediated products straddling the onset of the salinity crisis. Palaeogeography, Palaeoclimatology, Palaeoecology 344-345, 78-93.

Dela Pierre, F., Festa, A., Irace, A., 2007. Interaction of tectonic, sedimentary and diapiric processes in the origin of chaotic sediments: an example from the Messinian of Torino Hill (Tertiary Piedmont Basin, northwestern Italy). Geological Society of America Bulletin 119, 1107-1119.

Del Sordo, L., Brozzetti, F., Lavecchia, G., Marsella, E., Trincardi, G., in press. 339 Teramo sheet. Carta geologica d'Italia alla scala 1:50.000. Servizio Geologico d'Italia, Rome. http://www.isprambiente.gov.it/Media/carg/339_TERAMO/Foglio.html.

Di Stefano, A., Sturiale, G., 2010. Refinements of calcareous nannofossil biostratigraphy at the Miocene/Pliocene Boundary in the Mediterranean region. Geobios 43, 5-20.

Do Couto, D., Popescu, S.-M., Suc, J.-P., Melinte-Dobrinescu, M.C., Barhoun, N., Gorini, C., Jolivet, L., Poort, J., Jouannic, G., Auxietre, J.-L., 2014. Lago Mare and the Messinian Salinity Crisis: Evidences from the Alboran Sea (S. Spain). Marine and Petroleum Geology 52, 57-76. 
Doláková, N., Burešová, A., 2007. Use of fluorescent microscopy in the study of redeposited palynomorphs in the cave and marine sediments of Moravia (Czech Republic). Acta Palaeobotanica 47, 275-279.

Drivaliari, A., Țicleanu, N., Marinescu, F., Mărunțeanu, M., Suc, J.-P., 1999. A Pliocene climatic record at Ticleni (southwestern Romania), in: Wrenn, J.H., Suc, J.-P., Leroy, S.A.G. (Eds.), The Pliocene: Time of Change. American Association of Stratigraphic Palynologists Foundation, Dallas, pp. 103-108.

Esu, D., Girotti, O., 2008. The late Messinian Lago-Mare molluscan assemblage from the Trave Horizon (Colombacci Fm) at Pietralacroce (Ancona, Central Italy). Bolletino della Società Paleontologica Italiana 47, 123-129.

Esu, D., Popov, S.V., 2012. Revision of late Messinian Lymnocardiinae (Bivalvia) from Piedmont (NW Italy). Rivista Italiana di Paleontologia e Stratigrafia 118, 343-356. Esu, D., Taviani, M., 1989. Oligohaline mollusc fauna of the Colombacci Formation (upper Messinian) from an exceptional fossil vertebrate site in the Romagna Apennines: Monticino Quarry (Brisighella, N Italy). Bolletino della Società Paleontologica Italiana $28,265-270$.

Faranda, C., Gliozzi, E., Ligios, S., 2007. Late Miocene brackish Loxoconchidae (Crustacea, Ostracoda) from Italy. Geobios 40, 303-324.

Fauquette, S., Bernet, M., Suc, J.-P., Grosjean, A.-S., Guillot, S., van der Beek, P., Jourdan, S., Popescu, S.-M., Jiménez-Moreno, G., Bertini, A., Pittet, B., Tricart, P., Dumont, T., Schwartz, S., Zheng, Z., Roche, E., Pavia, G., Gardien, V., 2015a. Quantifying the Eocene to Pleistocene topographic evolution of the southwestern Alps, France and Italy. Earth and Planetary Science Letters 412, 220-234.

Fauquette, S., Bertini, A., Manzi, V., Roveri, M., Argnani, A., Menichetti, E., $2015 b$.

Reconstruction of the Northern and Central Apennines (Italy) palaeoaltitudes during the late Neogene from pollen data. Review of Palaeobotany and Palynology 218, 117-126.

Fontes, J.-C., Filly, A., Gaudant, J., 1987. Conditions de dépôt du Messinien évaporitique des environs d'Alba (Piémont): arguments paléontologiques et isotopiques. Bolletino della Società Paleontologica Italiana 26, 199-210.

Gartner, S., Bukry, D., 1974. Ceratolithus acutus n. sp. and Ceratolithus amplificus Bukry and Percival - nomenclatural clarification. Tulane Studies in Geology and Paleontology $11,115-118$. 
Gennari, R., Iaccarino, S.M., Di Stefano, A., Sturiale, G., Cipollari, P., Manzi, V., Roveri, M., Cosentino, D., 2008. The Messinian-Zanclean boundary in the Northern Apennine. Stratigraphy $5,307-322$.

Ghielmi, M., Minervini, M., Nini, C., Rogledi, S., Rossi, M., Vignolo, A., 2010. Sedimentary and tectonic evolution in the eastern Po-Plain and northern Adriatic Sea area from Messinian to Middle Pleistocene (Italy). Rendiconti Scienze Fisiche e Naturali dell'Accademia dei Lincei 21 (Suppl. 1), S131-S166.

Gillet, S., 1968. La faune messinienne des environs d'Ancona avec une notice géologique par E. Ceretti. Giornale di Geologia 36(1-4), 69-100.

Gliozzi, E., Ceci, M.E., Grossi, F., Ligios, S., 2007. Paratethyan Ostracod immigrants in Italy during the Late Miocene. Geobios 40, 325-337.

Gorini, C., Haq, B.U., dos Reis, T.A., Silva, C.G., Crus, A., Soares, E., Grangeon, D., 2014. Late Neogene sequence stratigraphic evolution of the Foz do Amazonas Basin, Brazil. Terra Nova 26, 179-185.

Harzhauser, M., Neubauer, T.A., Georgopoulou, E., Esu, D., D’Amico, C., Pavia, G., Giuntelli, P., Carnevale, G., 2015. Late Messinian continental and Lago-Mare gastropods from the Tertiaty Piedmont Basin, NW Italy. Bolletoni della Società Paleontologica Italiana 54, 1-53.

Harzhauser, M., Reuter, M., Mandic, O., Schneider, S., Piller, W.E., Brandano, M., 2013. "Pseudo-Sarmatian" mollusc assemblages from the early Messinian oolite shoals of Sicily (Italy). Rivista Italiana di Paleontologia e Stratigrafia 119, 351-386.

Hilgen, F.J., Lourens, L.J., Van Dam, J.A., 2012. The Neogene Period, in: Gradstein, F., Ogg, J., Schmitz, M., Ogg, G. (Eds.), The Geological Time Scale 2012. Elsevier, Amsterdam, 29, pp. 923-978.

Londeix, L., Benzakour, M., Suc, J.-P., Turon, J.-L., 2007. Messinian paleoenvironments and hydrology in Sicily (Italy): The dinoflagellate cyst record. Geobios 40, 233-250.

Luchetti, L., in press. VI. Schemi biostratigrafici e cronostratigrafici adottati. Note illustrative della carta geologica d'Italia alla scala 1:50.000, 339 Teramo sheet. Servizio Geologico d'Italia, Rome, pp. 46-48

(http://www.isprambiente.gov.it/Media/carg/note_illustrative/339_Teramo.pdf).

Lugli, S., Manzi, V., Roveri, M., Schreiber, B.C., 2010. The Primary Lower Gypsum in the Mediterranean: a new facies interpretation for the first stage of the Messinian salinity crisis. Palaeogeography, Palaeoclimatology, Palaeoecology 297, 83-99. 
Manzi V., Gennari R., Hilgen F., Krijgsman W., Lugli S., Roveri M., Sierro F.J., 2013. Age refinement of the Messinian salinity crisis onset in the Mediterranean. Terra Nova 25, $315-322$.

Manzi, V., Lugli, S., Ricci Lucchi, F., Roveri, M., 2005. Deep-water clastic evaporites deposition in the Messinian Adriatic foredeep (northern Apennines, Italy): did the Mediterranean ever dry out? Sedimentology 52, 875-902.

Marabini, S., Vai, G.B., 1985. Analisi di facies e macrotettonica della Vena del Gesso in Romagna. Bollettino della Società Geologica Italiana 104, 21-42.

Marabini, S., Vai, G.B., 1985. Analisi di facies e macrotettonica della Vena del Gesso in Romagna. Bollettino della Società Geologica Italiana 104, 21-42.

Marabini, S., Vai, G.B., 1988. Geology of the Monticino Quarry, Brisighella, Italy. Stratigraphic implications of its late Messinian mammal fauna, in: De Giuli, C., Vai, G.B. (Eds.), Fossil vertebrates in the Lamone Valley, Romagna Apennines. Field trip Guidebook. Università di Bologna, Università di Firenze, Comune di Faenza, pp. 3952.

Marabini, S., Vai, G.B., 1989. Geology of the Monticino Quarry, Brisighella, Italy. Stratigraphic implications of its late Messinian mammal fauna. Bollettino della Società Paleontologica Italiana 28, 369-382.

Mary, C., Iaccarino, S., Courtillot, V., Besse, J., Aissaoui, D.M., 1993. Magnetostratigraphy of Pliocene sediments from the Stirone River (Po Valley). Geophysical Journal International 112, 359-380.

Matano, F., 2007. The 'Evaporiti di Monte Castello' deposits of the Messinian Southern Apennines foreland basin (Irpinia-Daunia Mountains, Southern Italy): stratigraphic evolution and geological context. Geological Society, London, Special Publications $285,191-218$.

Matano, F., Barbieri, M., Di Nocera, S., Torre, M., 2005. Stratigraphy and strontium geochemistry of Messinian evaporate-bearing successions of the southern Apennines foredeep, Italy: implications for the Mediterranean "salinity crisis" and regional palaeogeography. Palaeogeography, Palaeoclimatology, Palaeoecology 217, 87-114.

Mattei, M., 1987. Analisi geologico-strutturale della Montagna dei Fiori (Ascoli Piceno, Italia central). Geologica Romana 26, 327-347.

Mazzoli, S., Deiana, G., Galdenzi, S., Cello, G., 2002. Miocene fault-controlled sedimentation and thrust propagation in the previously faulted external zones of the 
Umbria-Marche Apennines, Italy. European Geological Union Stephan Mueller Special Publication Series 1, 195-209.

Miljush, P., 1973. Geologic-tectonic structure and evolution of Outer Dinarides and Adriatic area. American Association of Petroleum Geologists Bulletin 57, 913-929.

Milli, S., Moscatelli, M., Stanzione, O., Falcini, F., 2007. Sedimentoligical and physical stratigraphy of the Messinian turbidite deposits of the Laga Basin (central Apennines, Italy). Bolletino della Società Geologica Italiana 126, 255-281.

Molenaar, N., De Feyter, A.J., 1985. Carbonates associated with alluvial fans: an example from the Messinian Colombacci Formation of the Pietrarubbia Basin, Northern Marche, Italy. Sedimentary Geology 42, 1-23.

Müller, C., 1974. Calcareous nannoplankton, Leg 25 (Western Indian Ocean), in: Simpson, E.S.W., Schlich, R. et al. (Eds.), Initial Reports of the Deep Sea Drilling Project 25, U.S. Government Printing Office, Washington, pp. 579-633.

Musacchio, A., Pellegrino, G., Cafasso, D., Widmer, A., Cozzolino, S., 2006. A unique $A$. palustris lineage across the Otranto strait: botanical evidence for a past land-bridge? Plant Systematics and Evolution 262, 103-111.

Patacca, E., Scandone, P., Mazza, P., 2008. Oligocene migration path for Apulia macromammals: the Central-Adriatic bridge. Bolletino della Società Geologica Italiana $127,337-355$.

Perch-Nielsen, K., 1985. Cenozoic calcareous nannofossils, in: Bolli, H.M. Saunders, J.B., Perch-Nielsen, K. (Eds.), Plankton Stratigraphy. Cambridge University Press, Cambridge, pp. 427-554.

Popescu, S.-M., 2006. Late Miocene and early Pliocene environments in the southwestern Black Sea region from high-resolution palynology of DSDP Site 380A (Leg 42B). Palaeogeography, Palaeoclimatology, Palaeoecology 238, 64-77.

Popescu, S.-M., Biltekin, D., Winter, H., Suc, J.-P., Melinte-Dobrinescu, M.C., Klotz, S., Combourieu-Nebout, N., Rabineau, M., Clauzon, G., Deaconu, F., 2010. Pliocene and Lower Pleistocene vegetation and climate changes at the European scale: Long pollen records and climatostratigraphy. Quaternary International 219, 152-167.

Popescu, S.-M., Dalesme, F., Jouannic, G., Escarguel, G., Head, M.J., Melinte-Dobrinescu, M.C., Sütő-Szentai, M., Bakrac, K., Clauzon, G., Suc, J.-P., 2009. Galeacysta etrusca complex, dinoflagellate cyst marker of Paratethyan influxes into the Mediterranean Sea before and after the peak of the Messinian Salinity Crisis. Palynology 33, 105-134. 
Popescu, S.-M., Dalibard, M., Suc, J.-P., Barhoun, N., Melinte-Dobrinescu, M.C., Bassetti, M.A., Deaconu, F., Head, M.J., Gorini, C., Do Couto, D., Rubino, J.-L., Auxietre, J.-L., Floodpage, J., 2015. Lago Mare episodes around the Messinian-Zanclean boundary in the deep southwestern Mediterranean. Marine and Petroleum Geology 66, 55-70.

Popescu, S.-M., Melinte, M.-C., Suc, J.-P., Clauzon, G., Quillévéré, F., Sütő-Szentai, M., 2008. Marine reflooding of the Mediterranean after the Messinian Salinity Crisis predates the Zanclean GSSP. Reply to the "Comment on 'Earliest Zanclean age for the Colombacci and uppermost Di Tetto formations of the "latest Messinian" northern Apennines: New palaeoenvironmental data from the Maccarone section (Marche Province, Italy)' by Popescu et al. (2007) Geobios 40 (359-373)" authored by Roveri et al. Geobios 41, 657-660.

Popescu, S.-M., Melinte-Dobrinescu, M.C., Suc, J.-P., 2016b. Objective utilization of data from DSDP Site 380 (Black Sea). Terra Nova 28, 228-229.

Popescu, S.-M., Melinte-Dobrinescu, M.C., Suc, J.-P., Do Couto, D., 2016a. Ceratolithus acutus Gartner and Bukry 1974 (=C. armatus Müller 1974), calcareous nannofossil marker of the marine reflooding that terminated the Messinian Salinity Crisis: Comment on "Paratethyan ostracods in the Spanish Lago-Mare: More evidence for interbasinal exchange at high Mediterranean sea level" by Stoica et al., 2016. Palaeogeogr., Palaeoclimatol., Palaeoecol., 441, 854-870. Palaeogeography, Palaeoclimatology, Palaeoecology, in press (doi: 10.1016/j.palaeo.2016.07.011).

Popescu, S.-M., Suc, J.-P., Melinte, M., Clauzon, G., Quillévéré, F., Sütő-Szentai, M., 2007. Earliest Zanclean age for the Colombacci and uppermost Di Tetto formations of the "latest Messinian" northern Apennines: New palaeoenvironmental data from the Maccarone section (Marche Province, Italy). Geobios 40, 359-373.

Raffi, I., Backman, J., Fornaciari, E., Pälike, H., Rio, D., Lourens, L., Hilgen, F., 2006. A review of calcareous nannofossil astrobiochronology encompassing the past 25 million years. Quaternary Science Reviews 25, 3113-3137.

Ricci Lucchi, F., 1986. The Oligocene to Recent foreland basins of the northern Apennines. International Association of Sedimentologists Special Publications 8, 105-139.

Rook, L., Delfino, M., Sami, M., 2015. I vertebrati fossili della cava del Monticino di Brisighella: una finestra sui popolamenti continentali del Mediterraneo nel Miocene superiore. Memorie dell'Istituto Italiano di Speleologia 28, ser. II, 55-76.

Rossi, M., Minervini, M., Ghielmi, M., Rogledi, S., 2015. Messinian and Pliocene erosional surfaces in the Po Plain-Adriatic Basin: insights from allostratigraphy and sequence 
stratigraphy in assessing play concepts related to accommodation and gateway turnarounds in tectonically active margins. Marine and Petroleum Geology 66, 192216.

Roveri, M., Bassetti, M.A., Ricci Lucchi, F., 2001. The Mediterranean Messinian salinity crisis: an Apennine foredeep perspective. Sedimentary Geology 140, 201-214.

Roveri, M., Bertini, A., Cipollari, P., Cosentino, D., Di Stefano, A., Florindo, F., Gennari, R., Gliozzi, E., Grossi, F., Iaccarino, S., Lugli, S., Manzi, V., 2008b. Comment on “Earliest Zanclean age for the Colombacci and uppermost Di Tetto formations of the "latest Messinian" northern Apennines: New palaeoenvironmental data from the Maccarone section (Marche Province, Italy)" by Popescu et al. (2007) Geobios 40 (359-373). Geobios 41, 669-675.

Roveri, M., Flecker, R., Krijgsman, W., Lofi, J., Lugli, S., Manzi, V., Sierro, F.J., Bertini, A., Camerlenghi, A., De Lange, G., Govers, R., Hilgen, F.J., Hübscher, C., Meijer, P.Th., Stoica, M., 2014. The Messinian Salinity Crisis: Past and future of a great challenge for marine sciences. Marine Geology 352, 25-58.

Roveri, M., Gallo, A.B., Rossi, M., Gennari, R., Iaccarino, S.M., Lugli, S., Manzi, V., Negri, A., Rizzini, F., Taviani, M., 2005. The Adriatic foreland record of Messinian events (Central Adriatic Sea, Italy). GeoActa 4, 139-157.

Roveri, M., Manzi, V., 2006. The Messinian salinity crisis: looking for a new paradigm? Palaeogeography, Palaeoclimatology, Palaeoecology 238, 386-398.

Roveri, M., Manzi, V., Bassetti, M.A., Metini, M., Ricci Lucchi, F., 1998. Stratigraphy of the Messinian post-evaporitic stage in eastern Romagna (northern Apennines, Italy). Giornale di Geologia 60, ser. 3, 119-142.

Roveri, M., Manzi, V., Gennari, R., Iaccarino, S.M., Lugli, S., 2008a. Recent advancements in the Messinian stratigraphy of Italy and their Mediterranean-scale implications. Bolletino della Società Paleontologica Italiana 47, 71-85.

Sampalmieri, G., Iadanza, A., Cipollari, P., Cosentino, D., Lo Mastro, S., 2010.

Palaeoenvironments of the Mediterranean Basin at the Messinian hypersaline/hyposaline transition: evidence from natural radioactivity and microfacies of post-evaporitic successions of the Adriatic sub-basin. Terra Nova 22, 239-250.

Scarselli, S., Simpson, G.D.H., Allen, P.A., Minelli, G., Gaudenzi, L., 2007. Association between Messinian drainage network formation and major tectonic activity in the Marche Apennines (Italy). Terra Nova 19, 74-81. 
Selli, R., 1952. Su un livello-guida nel Messiniano romagnolo-marchigiano. Atti del VII Convegno Nazionale del Metano e Petrolio, Taormina 1, 192-195.

Selli, R., 1954. Il bacino del Metauro. Giornale di Geologia 24, ser. 2, 1-254.

Selli, R., 1973. An outline of the Italian Messinian, in: Drogger, C.W., Broekman, J.A., Hageman, J., Hantelman, J.J., Marks, P., Meulenkamp, J.E., Schmidt, R.R. (Eds.), Messinian events in the Mediterranean. Koninklijke Nederlandse Akademie Van Wetenschappen, North-Holland Publishing Company, Amsterdam, London, pp. 150171.

Senatore, M.R., Boscaino, M., Roberto, A., Pinto, F., 2012. The evaporitic succession of Monte Castello (Savignano Irpino, Campania). Stratigraphy and facies analysis. Rendiconti Online della Società Geologica Italiana 21, 106-108.

Snel, E., Mărunțeanu, M., Macaleț, R., Meulenkamp, J.E., van Vugt, N., 2006. Late Miocene to Early Pliocene chronostratigraphic framework for the Dacic Basin, Romania. Palaeogeography, Palaeoclimatology, Palaeoecology 238, 107-124.

Sprovieri, R., Di Stefano, E., Bonomo, S., Tamburini, F., McKenzie, J., 2007. The Messinian - Pliocene boundary in the north Italy. Geophysical Research Abstracts 9, 06041.

Stoica, M., Lazăr, I., Vasiliev, I., Krijgsman, W., 2007. Mollusc assemblages of the Pontian and Dacian deposits from the Topolog-Argeș area (southern Carpathian foredeep Romania). Geobios 40, 391-405.

Sturani, C., 1973. A fossil eel (Anguilla sp.) from the Messinian of Alba (Tertiary Piedmontese Basin). Palaeoenvironmental and palaeogeographic implications, in: Drogger, C.W., Broekman, J.A., Hageman, J., Hantelman, J.J., Marks, P., Meulenkamp, J.E., Schmidt, R.R. (Eds.), Messinian events in the Mediterranean. Koninklijke Nederlandse Akademie Van Wetenschappen, North-Holland Publishing Company, Amsterdam, London, pp. 243-255.

Suc, J.-P., Do Couto, D., Melinte-Dobrinescu, M.C., Macaleț, R., Quillévéré, F., Clauzon, G., Csato, I., Rubino, J.-L., Popescu, S.-M., 2011. The Messinian Salinity Crisis in the dacic basin (SW Romania) and early Zanclean Mediterranean - Paratethys high sealevel connection. Palaeogeography, Palaeoclimatology, Palaeoecology 310, 256-272.

Suc, J.-P., Gillet, H., Çağatay, M.N., Popescu, S.-M., Lericolais, G., Armijo, R., MelinteDobrinescu, M.C., Șen, Ș., Clauzon, G., Sakınç, M., Zabcı, C., Ucarkus, G., Meyer, B., Çakir, Z., Karakaş, Ç., Jouannic, G., Macaleț, R., 2015. The region of the Strandja Sill (North Turkey) and the Messinian events. Marine and Petroleum Geology 66, 1, 149164. 
Taviani, M., 1988. Mollusk associated with the late Messinian vertebrate remains (Monticino Quarry, Faenza), in: De Giuli, C., Vai, G.B. (Eds.), Fossil vertebrates in the Lamone Valley, Romagna Apennines. Field trip Guidebook. Università di Bologna, Università di Firenze, Comune di Faenza, pp. 59-60.

Trenkwalder, S., Violanti, D., D’Atri, A., Lozar, F., Dela Pierre, F., Irace, A., 2008. The Miocene/Pliocene boundary and the Early Pliocene micropaleontological record: new data from the Tertiary Piedmont Basin (Moncucco quarry, Torino Hill, Northwestern Italy). Bollettino della Società Paleontological Italiana 47, 87-103.

Vai, G.B., 2016. Over half a century of Messinian salinity crisis. Boletin Geológico y Minero $127,615-632$.

Vai, G.B., Ricci Lucchi, F., 1977. Algal crusts, autochthonous and clastic gypsum in a cannibalistic evaporate basin: a case history from the Messinian of Northern Apennines. Sedimentology 24, 211-244.

Van Gijzel, P., 1967. Palynology and fluorescence microscopy. Review of Palaeobotany and Palynology 2, 49-79.

Vezzani, L., Festa, A., Ghisetti, F.C., 2010. Geology and tectonic evolution of the CentralSouthern Apennines, Italy. Geological Society of America, Special Paper 469, 1-58. Violanti, D., Dela Pierre, F., Trenkwalder, S., Lozar, F., Clari, P., Irace, A., D’Atri, A., 2011. Biostratigraphic and palaeoenvironmental analyses of the Messinian/Zanclean boundary and Zanclean succession in the Moncucco quarry (Piedmont, Northwestern Italy).

Bulletin de la Société géologique de France 182, 149-162.

Warny, S.A, Wrenn, J.H., 2002. Upper Neogene dinoflagellate cysts of the Atlantic coast of Morocco. Micropaleontology 48, 257-272.

Young, J.R., 1998. Chapter 9: Neogene, in: Bown, P.R. (Ed.), Calcareous Nannofossils Biostratigraphy. British Micropaleontological Society Publications Series, Kluwer Academic Press, Dordrecht, pp. 225-265. 


\section{Figure captions}

Fig. 1. Present-day Mediterranean region compared to reconstruction just after the Messinian Salinity Crisis (Bache et al., 2012), with location of the studied sections in the Apennine foredeep.

Fig. 2. The Apennine foredeep. a. Simplified geological map (after Compagnoni et al., 2005; Roveri et al., 2005; Ghielmi et al., 2010; Vezzani, 2010; Artoni, 2013) with location of the studied sections shown in b. b. Schematic geological section from Romagna to Apulia focussing on Messinian and Zanclean deposits (modified from Roveri et al., 2008a) with correlations between the studied successions. Sediment thickness not to scale.

Fig. 3. Calcareous nannofossil distribution in the studied sections.

Fig. 4. The Monticino section near Brisighella. a. Monticino quarry located on a Google Earth image, with geology after Marabini and Vai (1988). b. Overview of the Primary Lower Gypsum beds (Gessoso-Solfifera Fm.) cut by the Messinian erosion and overlain by thin Colombacci deposits and the Zanclean Argille Azzurre. Rectangle c: first sampling site on the northern margin of the quarry. c. Detailed position of samples 1-5. d. Sedimentary log of the section overlying the Messinian Erosional Surface. e. Sedimentary log of the section within the karstic fissure $n^{\circ} 8$ bis. f. Sampling site of the the karstic fissure $n^{\circ} 8$ bis (e) on the southern margin of the quarry. g. Detailed position of samples 6-8 within the karstic fissure ${ }^{\circ} 8$ bis.

Fig. 5. The Maccarone section near Apiro. a. Maccarone section located on a Google Earth image, with geology after Centamore et al. (1991). b. The Maccarone section with position of the studied samples. c. Lithology and sample location of the studied part of the section.

Fig. 6. The upper Messinian succession at Civitella del Tronto. a. Studied segments of the section located on a Google Earth image, with geology after Del Sordo et al. (in press) and Albouy et al. (2002). The segments are within the $p-e_{2}$ Fm. b. Sedimentary log of the studied section and position of the analysed samples. c. Photograph of samples 50 and 51 bordering a Colombacci carbonate bed. d. Photograph of samples 30 and 31 from a mudstone interval. 
Fig. 7. The Fonte dei Pulcini section near Lama dei Peligni. a. Fonte dei Pulcini section located on a Google Earth image, with geology after Cosentino et al. (2005). b. Sedimentary $\log$ of the studied section and position of the analysed samples. c. Position of samples in the upper part of the Fonte dei Pulcini section A of Cosentino et al. (2005).

Fig. 8. The Fonte la Casa section near Palmoli. a. Fonte la Casa section located on a Google Earth image, with geology after Balboni (1968). b. Sedimentary log of the studied section and position of the analysed samples. c. Photograph of the lower part of the section rich in mollusc shells where sample 1 was taken. $\mathbf{d}$. Detailed photograph of this section showing mollusc shells. e. Photograph of the upper part of the section comprising yellow sands with intercalated clayey beds where samples 2 and 3 were taken. f. Photograph of sample 2. g. Photograph of sample 3.

Fig. 9. Dinoflagellate cysts from the Monticino section: marine assemblages. Lithology: see Fig. 4. 4: Peak corresponding to marine influx (see text for details).

Fig. 10. Dinoflagellate cysts from the Maccarone section (Popescu et al., 2007), showing the variations in Paratethyan (brackish) vs. marine assemblages. Lithology: see Fig. 5.1 to 4: Peaks corresponding to successive marine influxes.

Fig. 11. Dinoflagellate cysts from the Civitella del Tronto section, showing the variations in Paratethyan (brackish) vs. marine assemblages. Lithology: see Fig. 6.2 to 4: Peaks corresponding to successive marine influxes.

Fig. 12. Dinoflagellate cysts from the Fonte dei Pulcini section, showing the variations in Paratethyan (brackish) vs. marine assemblages. Lithology: see Fig. 7. 3: Peak corresponding to marine influx.

Fig. 13. Dinoflagellate cysts from the Fonte la Casa section, showing the variations in Paratethyan (brackish) vs. marine assemblages. Lithology: see Fig. 8. Unnumbered peak(s) corresponding to marine influx(es).

Fig. 14. Chronostratigraphic and palaeoenvironmental re-interpretation of the Messinian postevaporitic deposits of the Apennine foredeep. 1 to 4: Marine dinoflagellate cyst peaks. 
Fig. 15. Mediterranean-Adriatic (vs. Apennine foredeep) connections since 6 Ma. a. Location of the cross-sections. b. Present-day cross-section. c. Successive reconstructed cross-sections from 5.97 to 5.33 Ma, highlighting the role of the Gargano-Pelagosa palaeo-sill and Messinian Apennine deformation phase.

Fig. 16. Line drawings of interpreted seismic profiles in the Adriatic Sea showing the Messinian Gargano-Pelagosa palaeo-sill. 


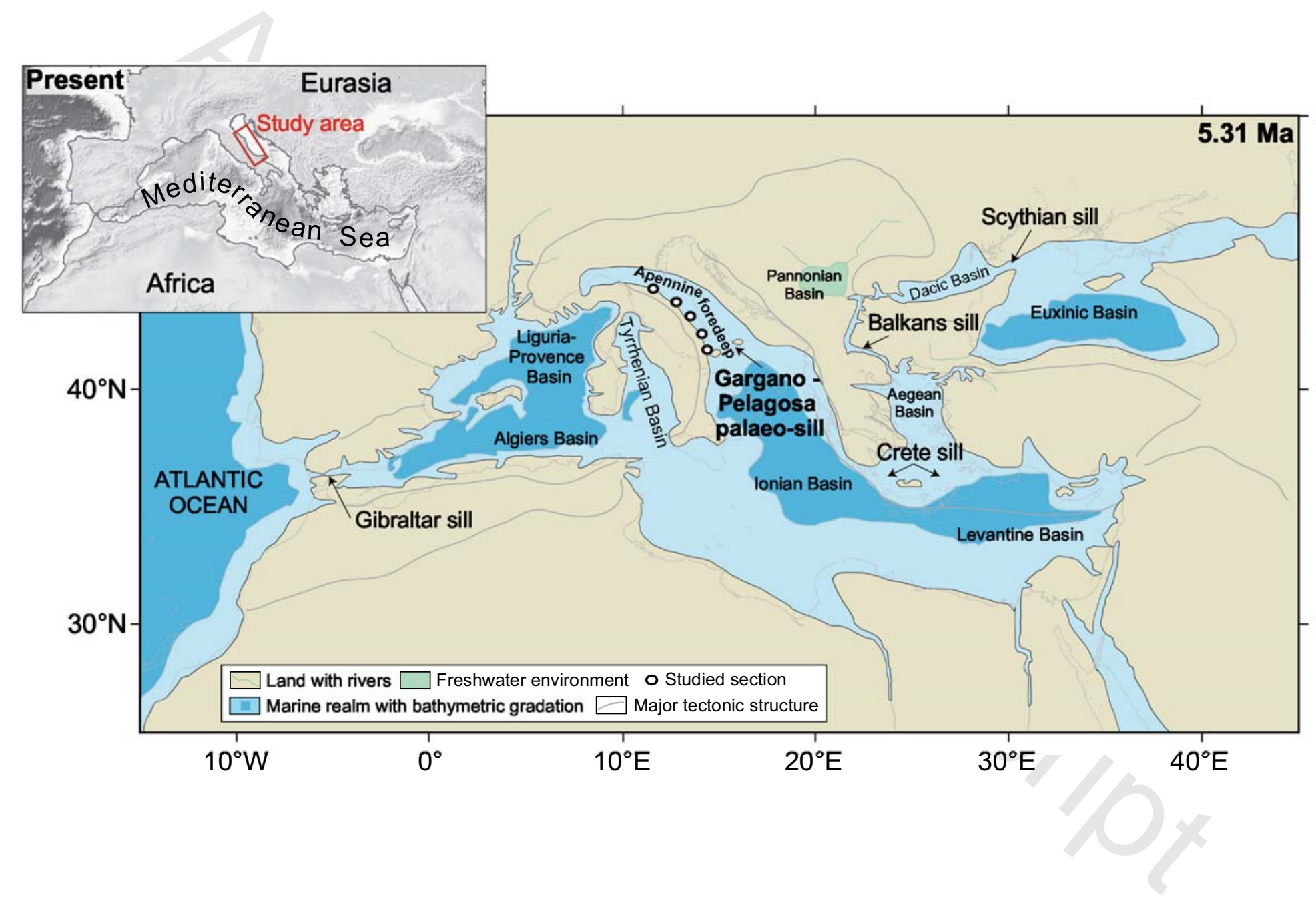



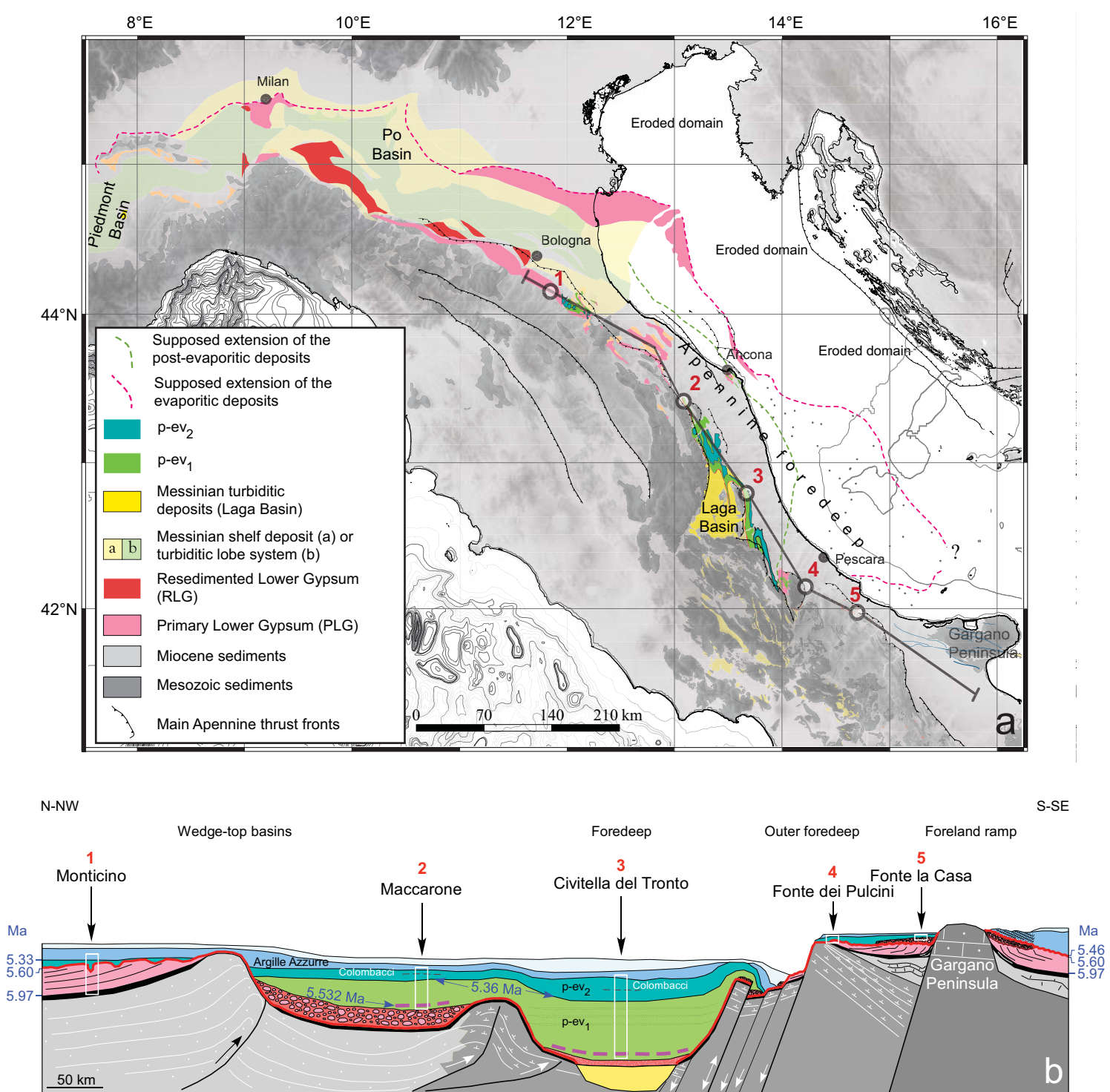

Piacenzian and Quaternary: Messinian

Pre-Messinian

$\square$ Piacenzian and Quaternary clays $\square$ Turbidites and Colombacci unit (p-ev ${ }_{2} \mathrm{Fm}$.) $\square$ Messinian Erosional Surface

$\square$ Zanclean clays (Argille Azzurre) $\quad-\quad$ Ash horizon

$\square$ Primary Lower Gypsum

$\square$ Laga Fm. 


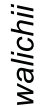

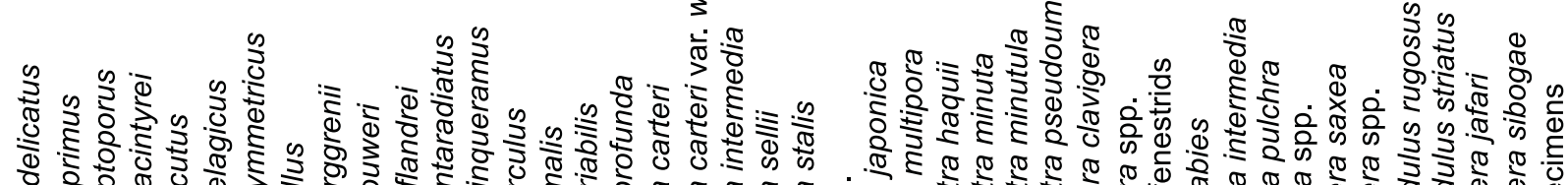
क人

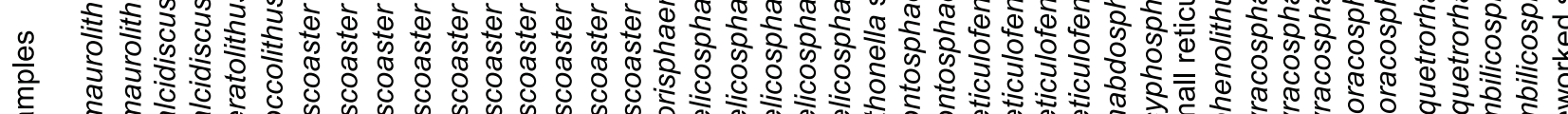

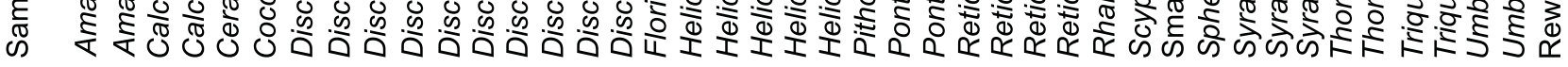

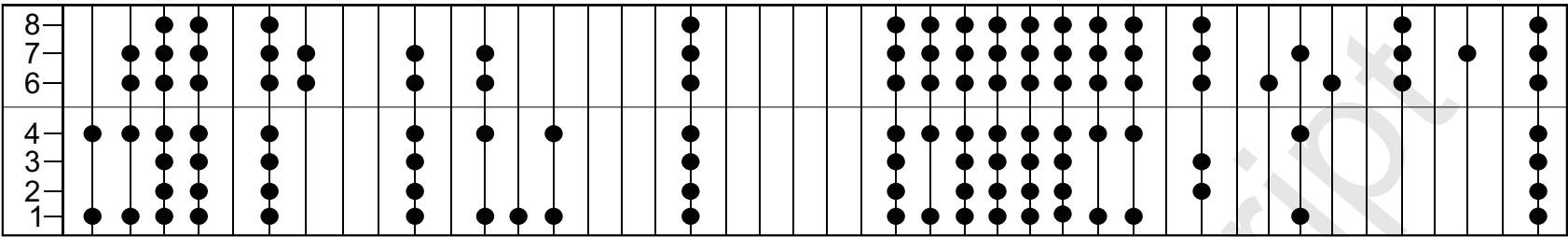

Monticino

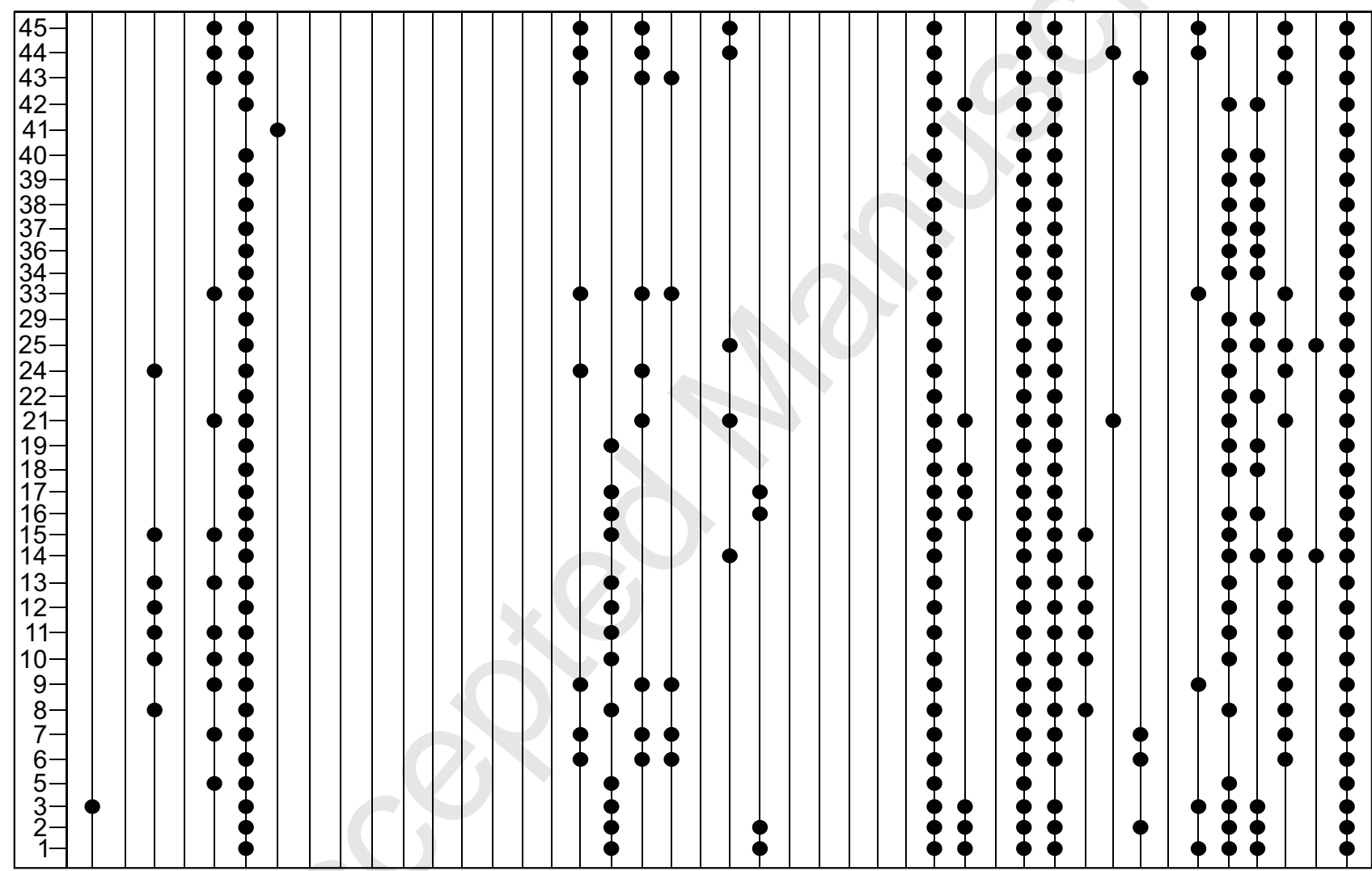

Maccarone

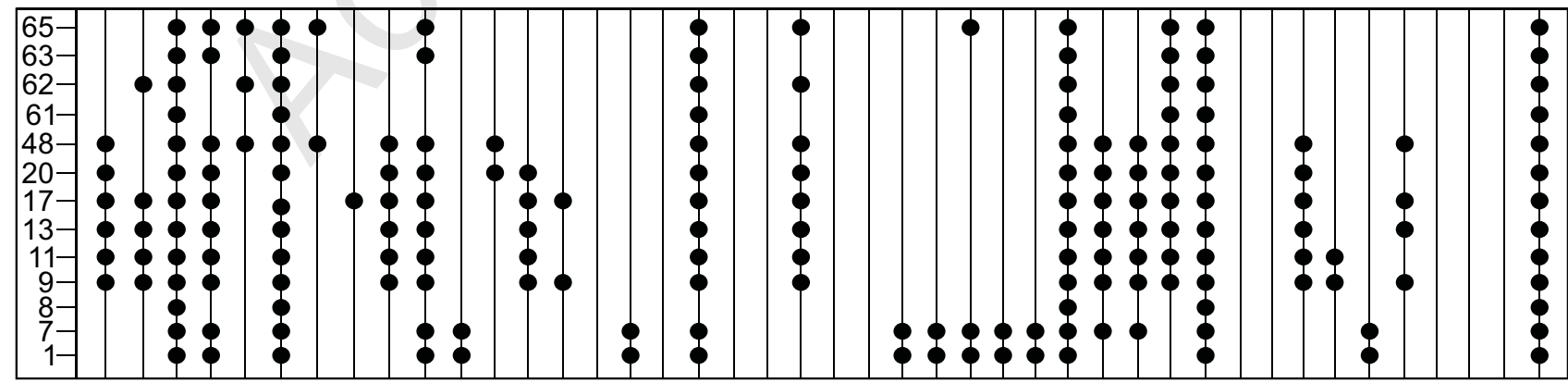

Civitella del Tronto

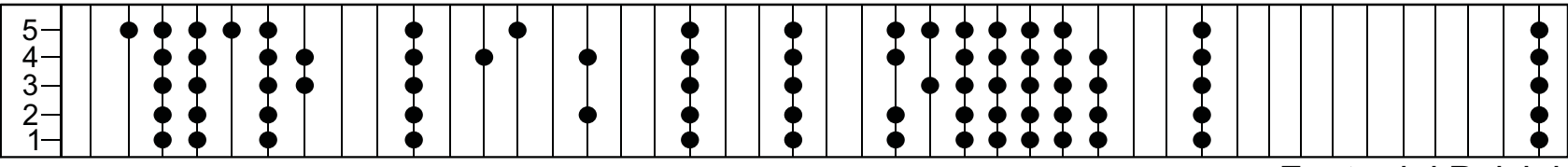

Fonte dei Pulcini

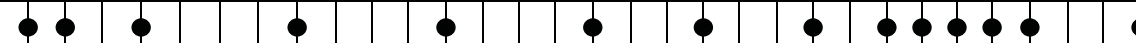

Fonte la Casa 


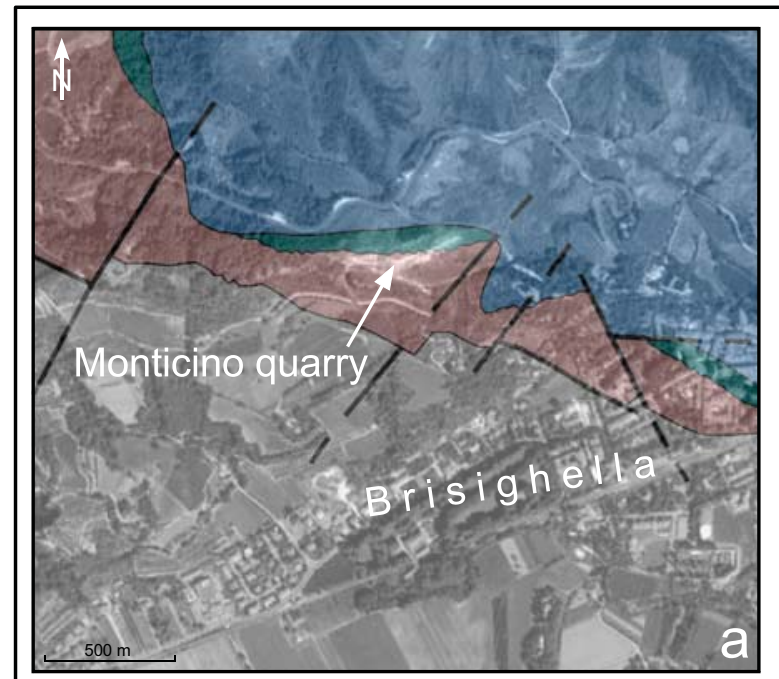

Argille Azzurre (Lower Zanclean)

Colombacci deposits ( $p-\mathrm{ev}_{2}$ Formation)

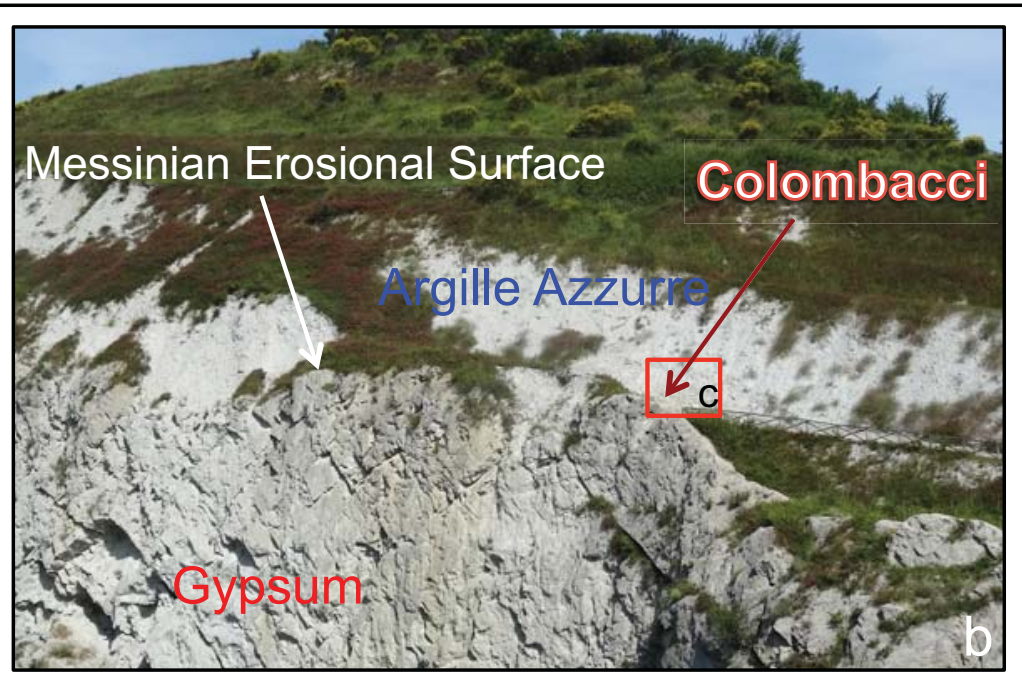

$\square$ Messinian Primary Lower Gypsum

Pre-evaporitic Miocene deposits

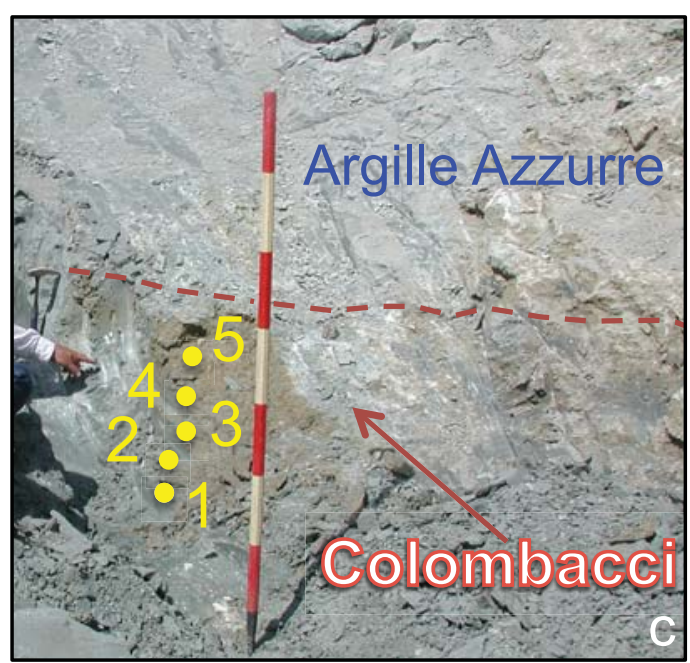

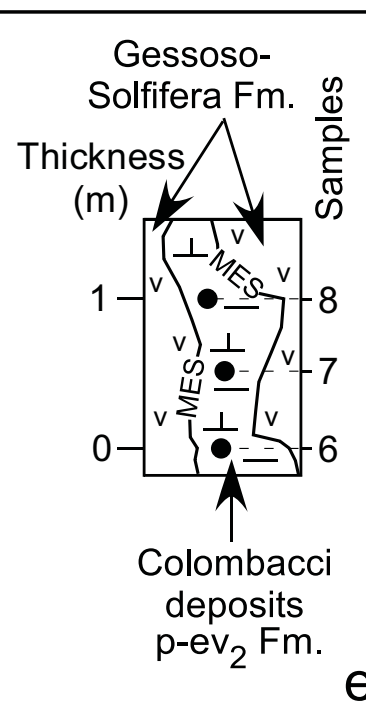

e

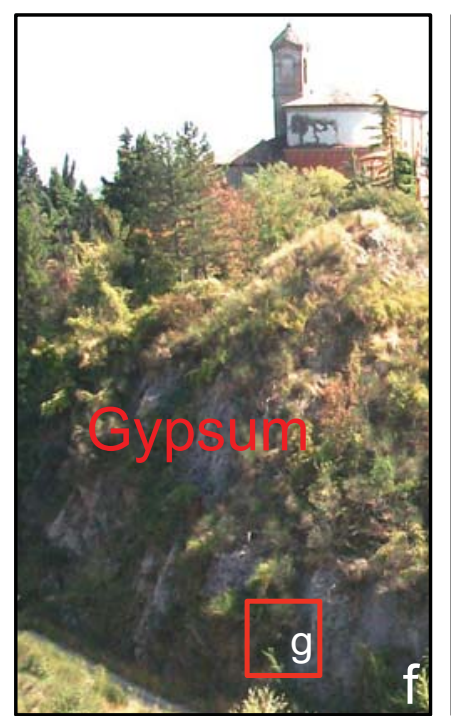

Fault

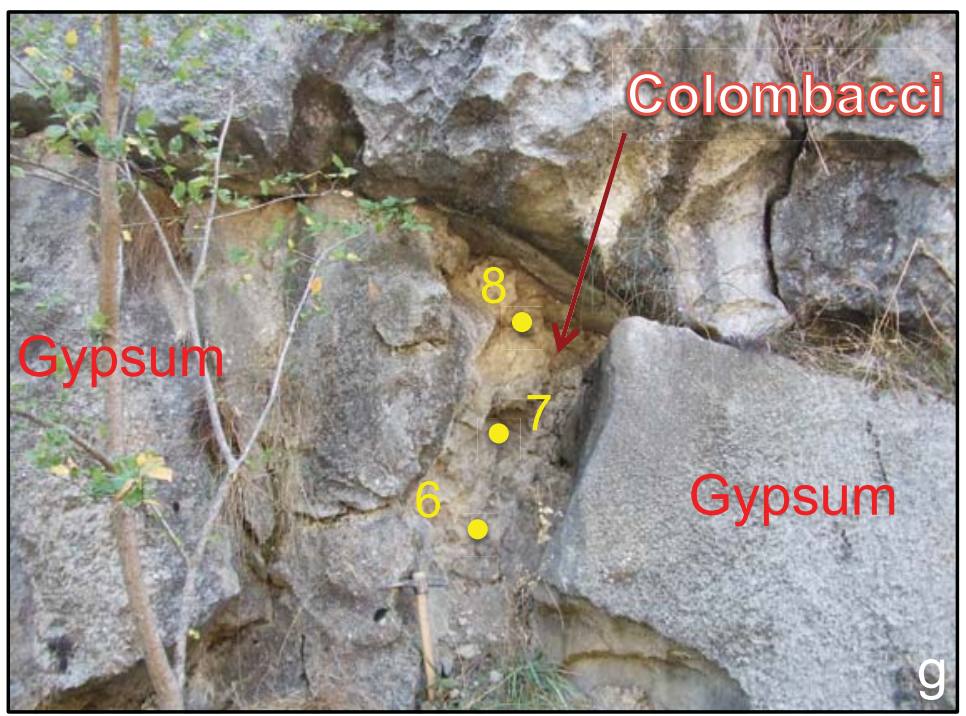

V Gypsum

MES Messinian Erosional Surface 


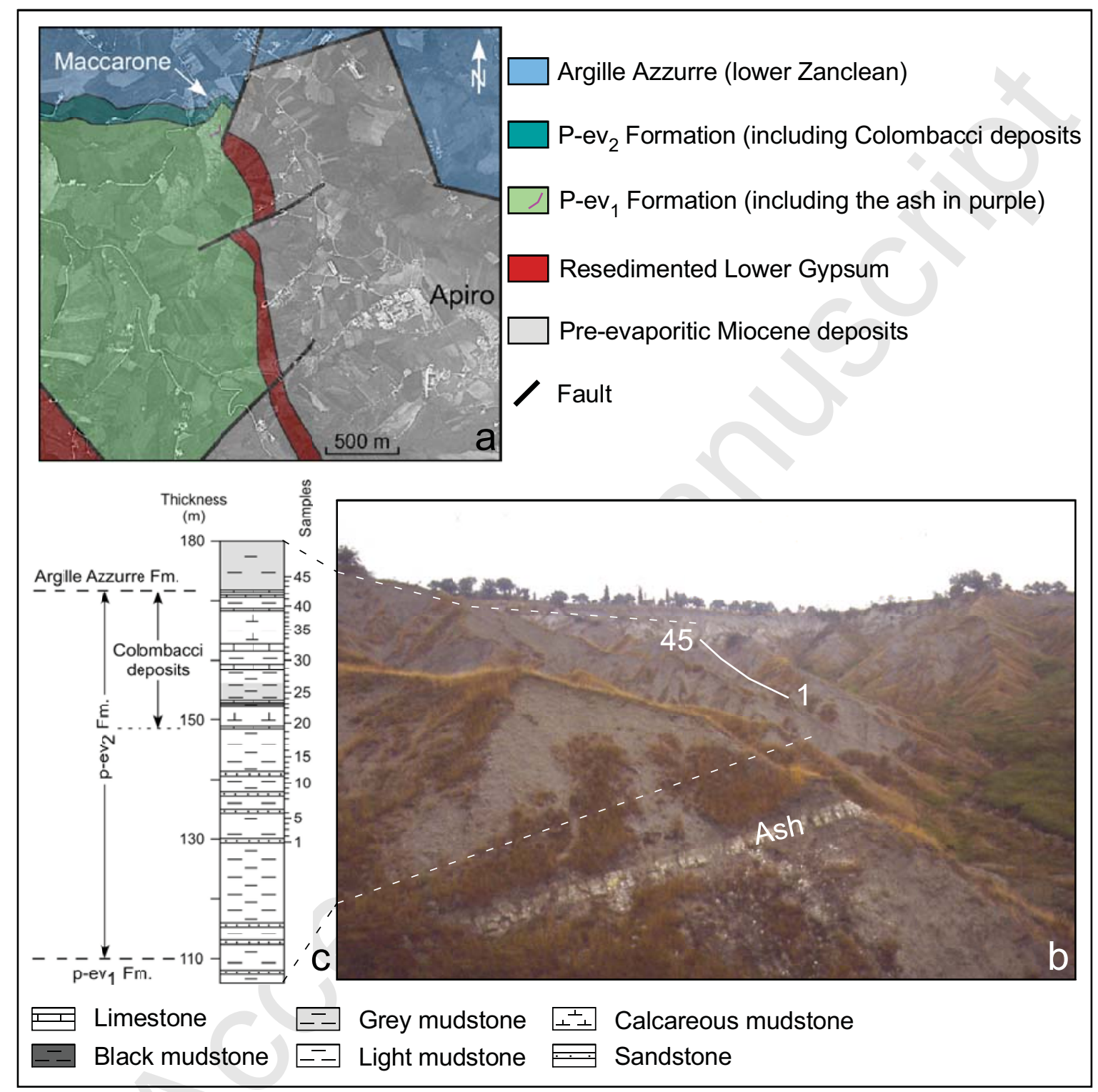




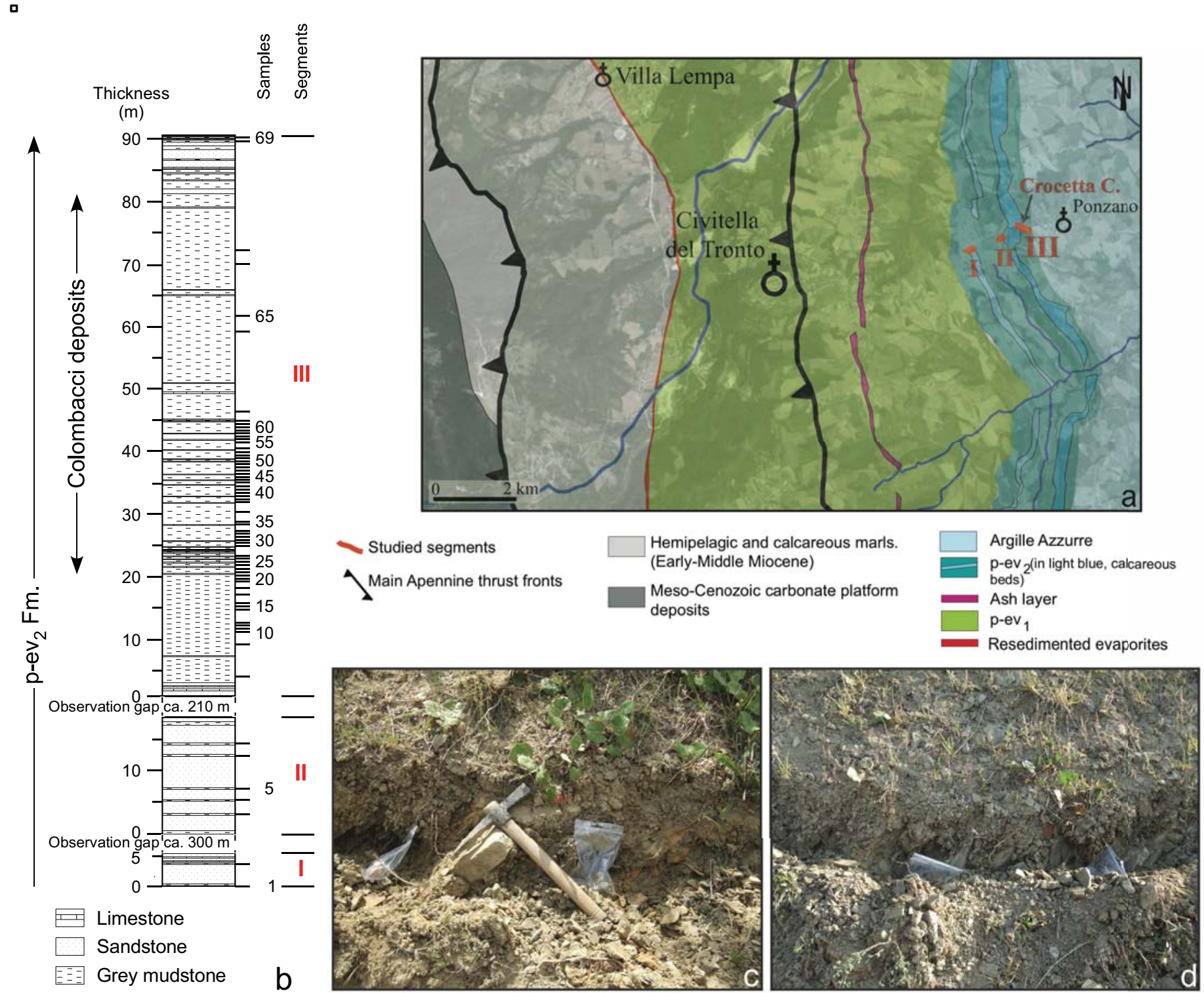




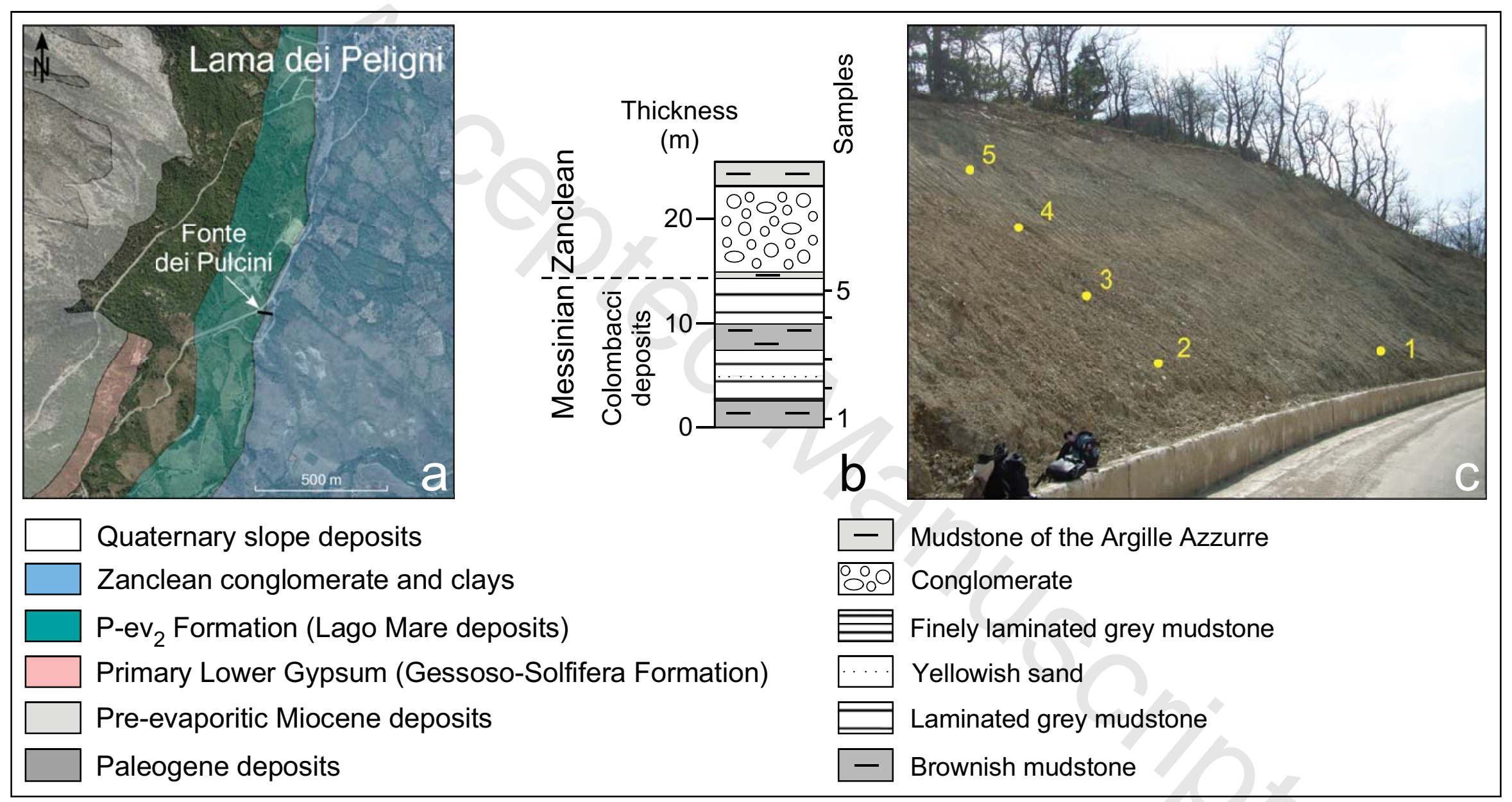




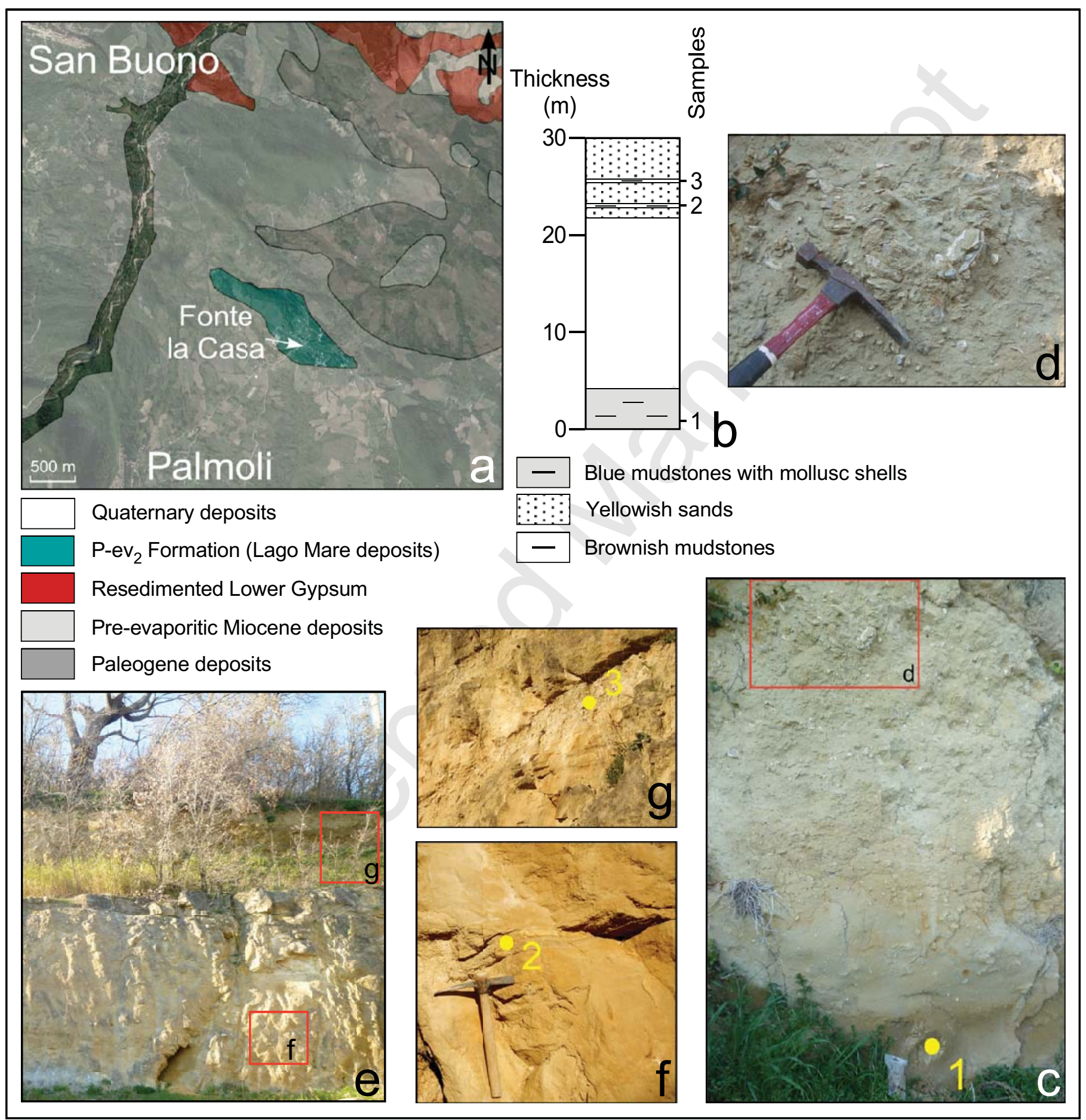




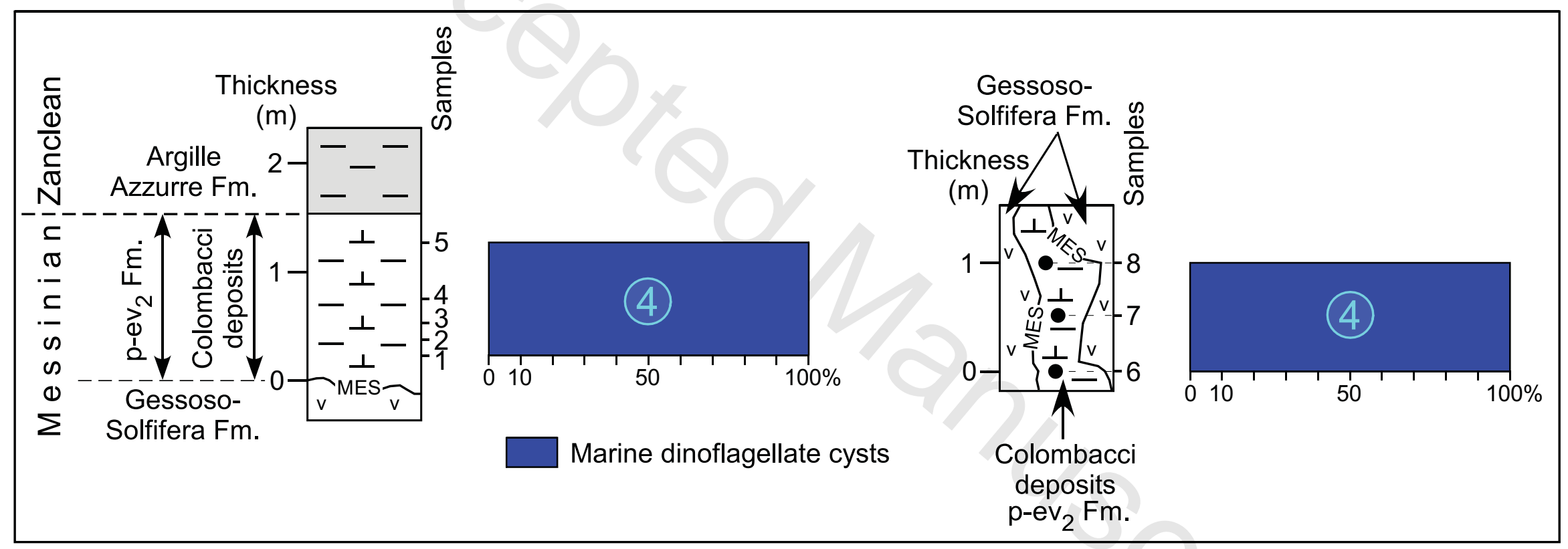




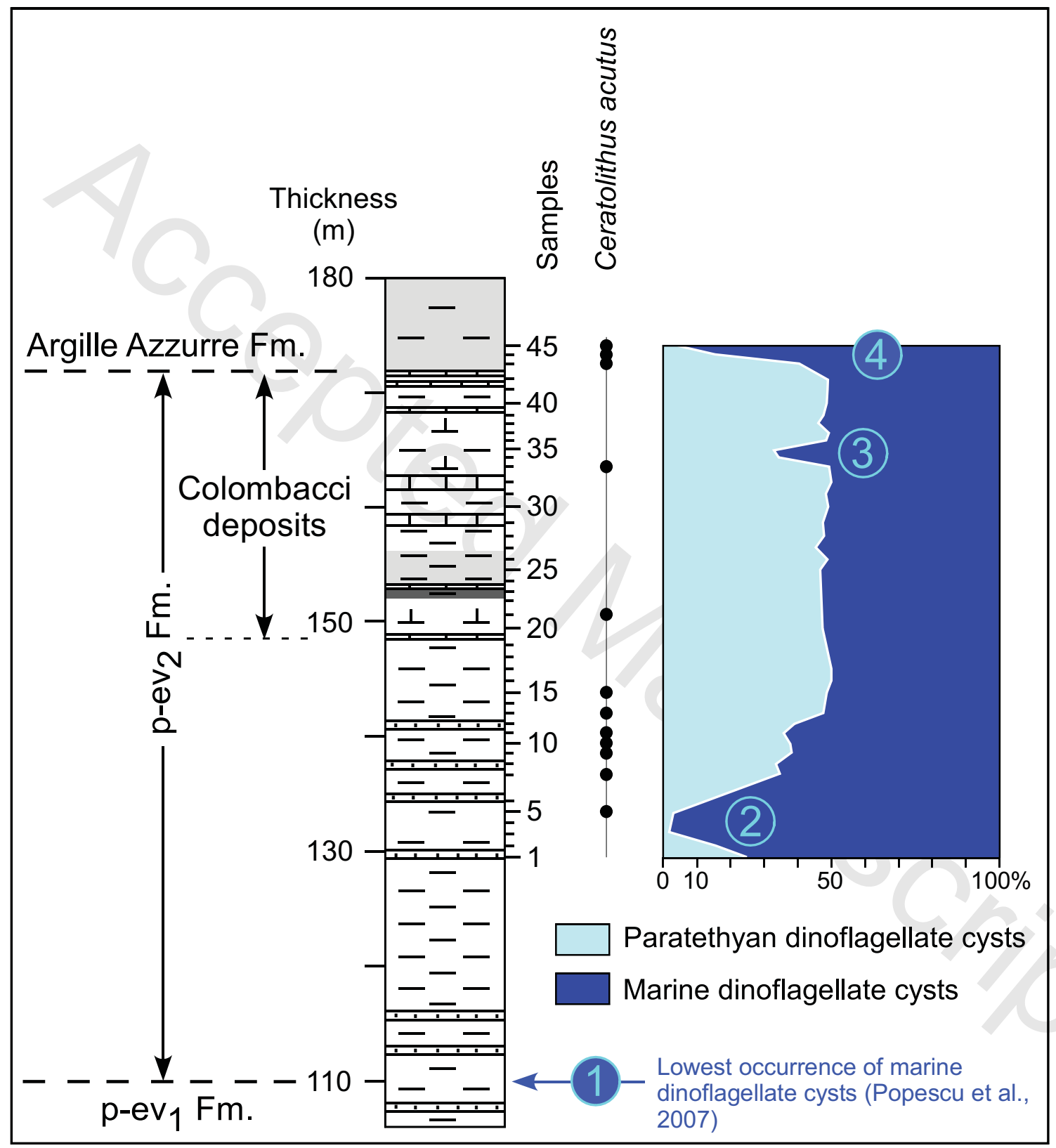




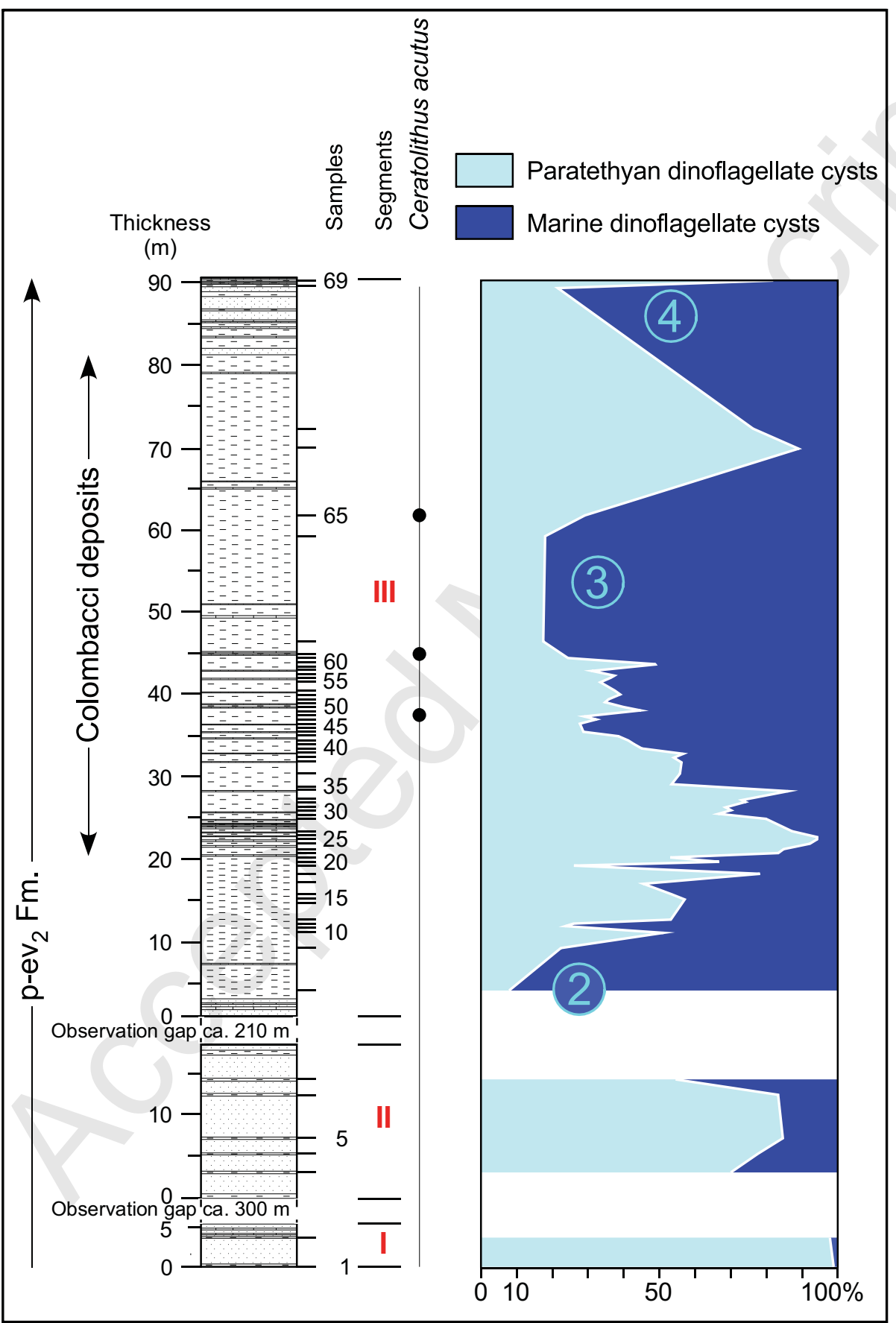




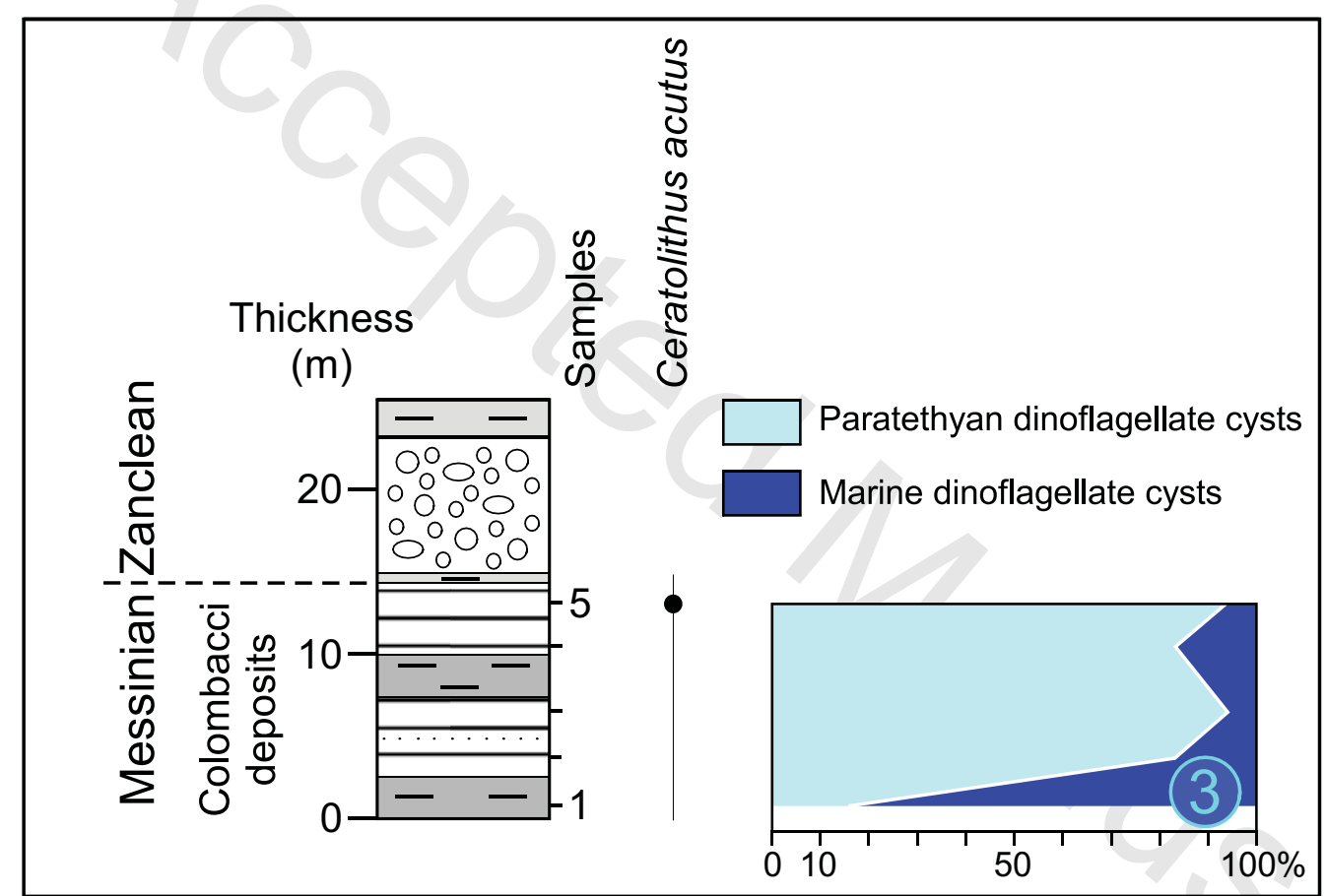




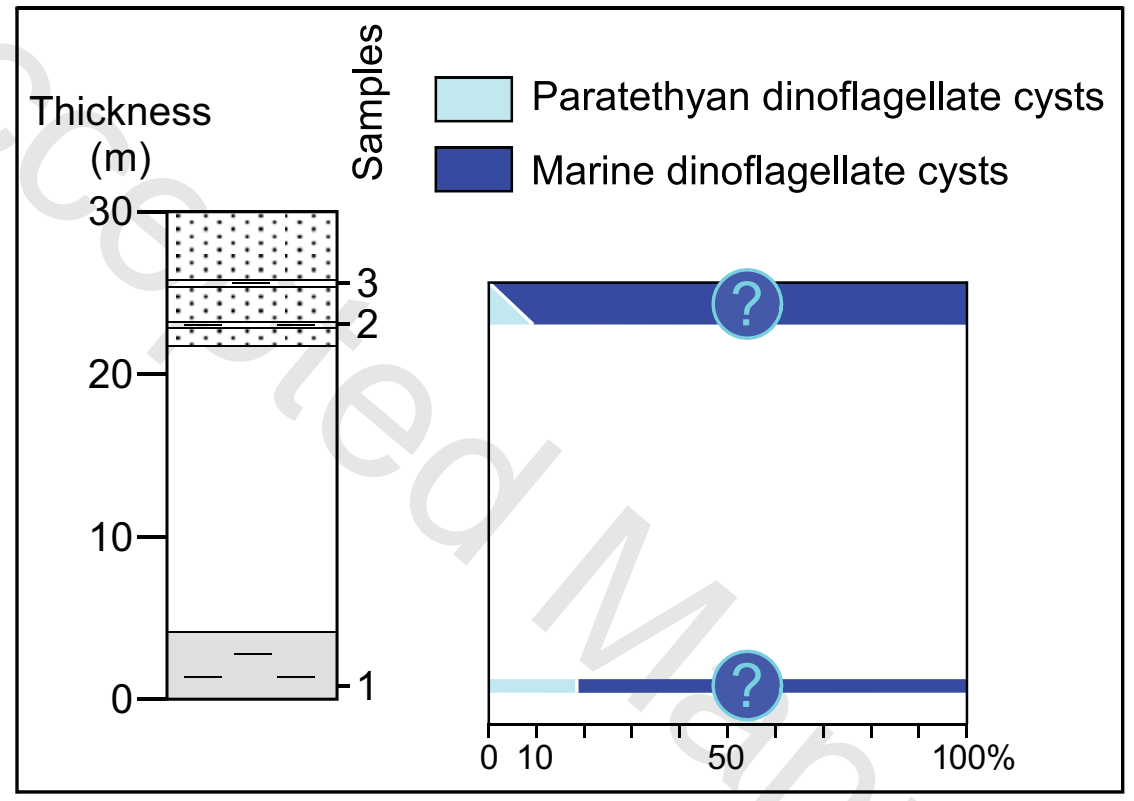




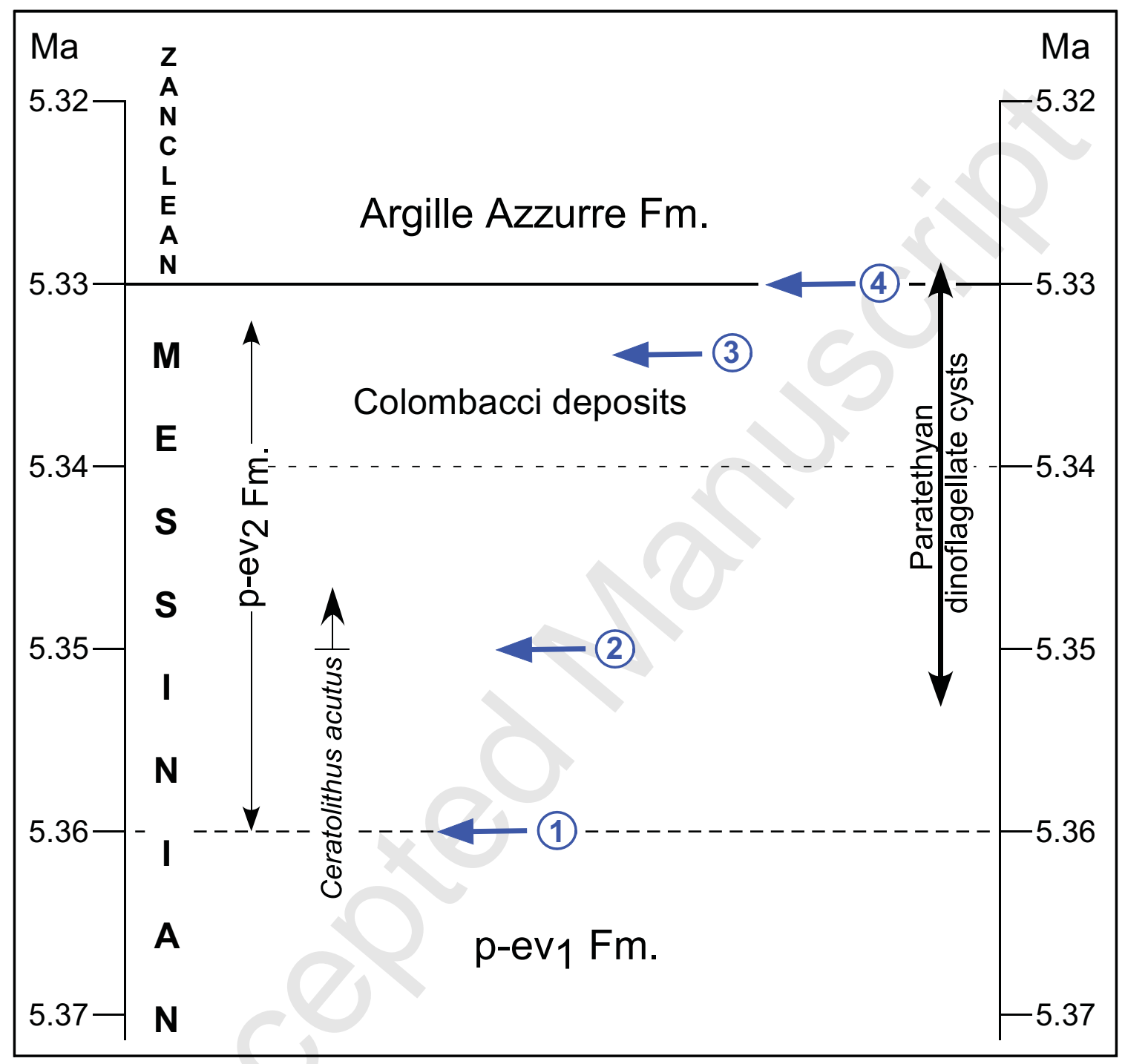




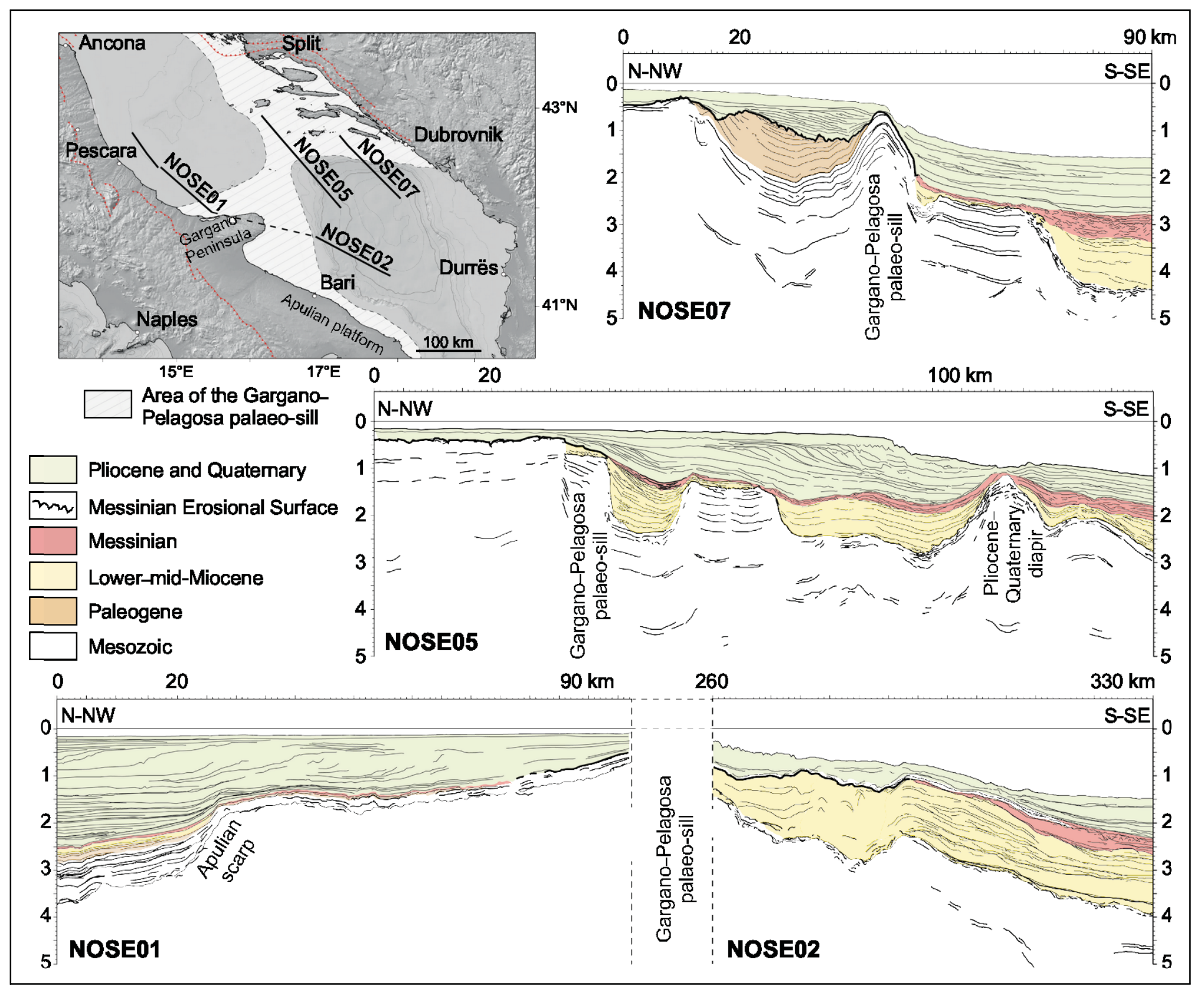




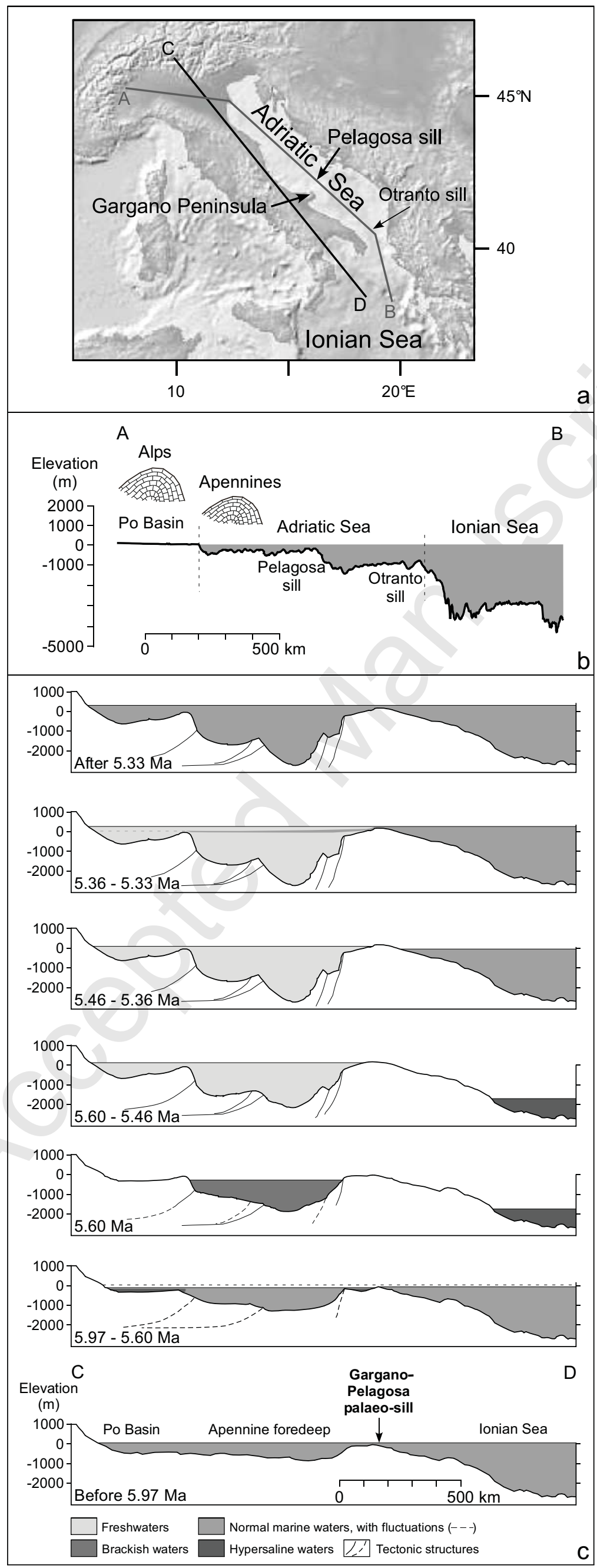



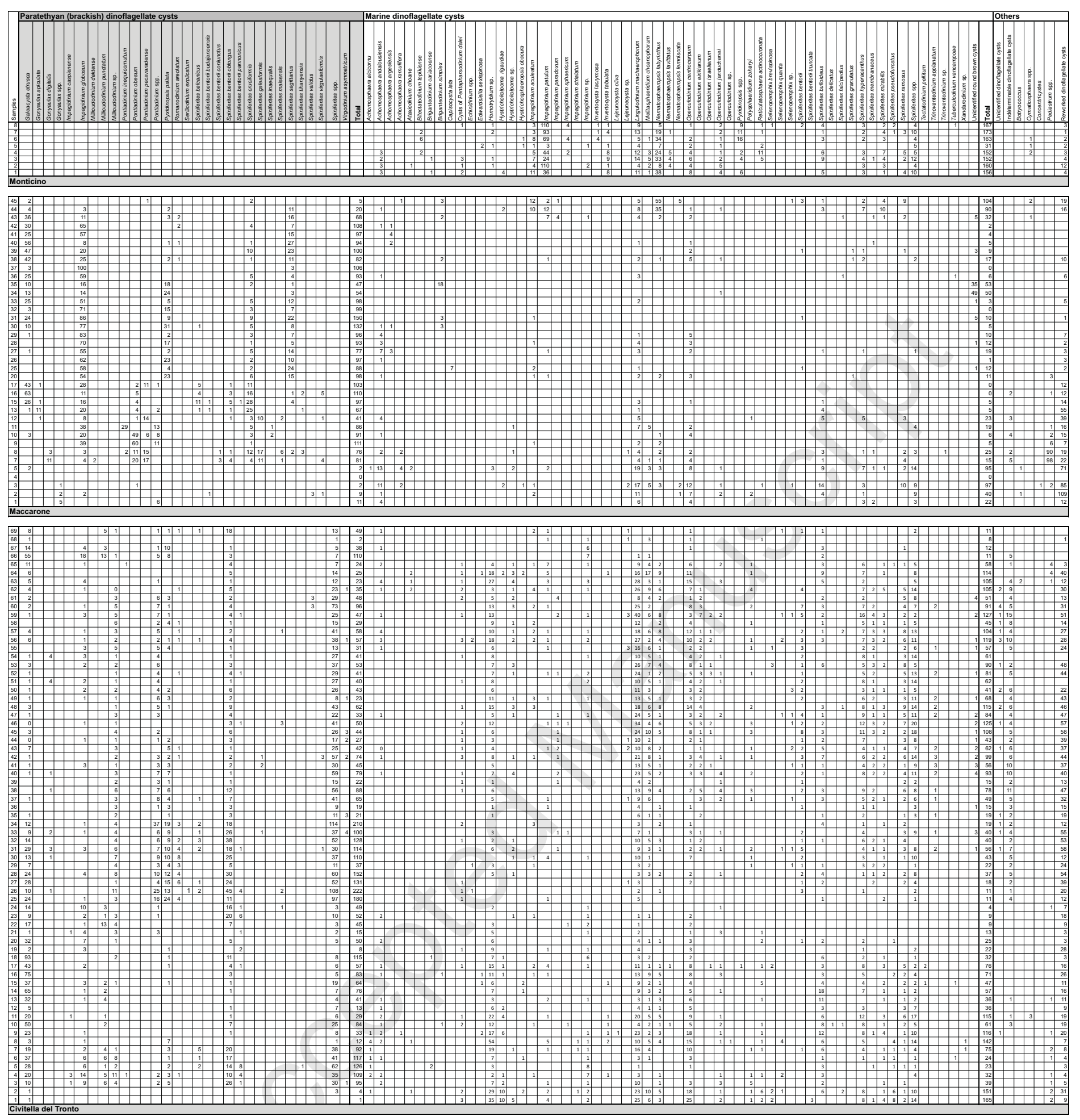

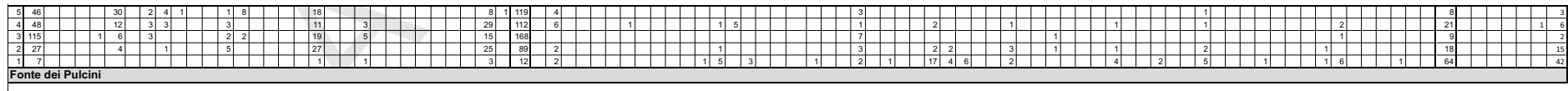

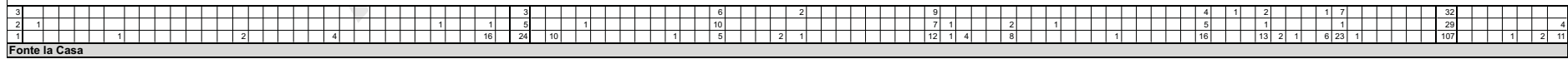

